\title{
Hormonal Therapy for Gynecological Cancers: How Far Has Science Progressed toward Clinical Applications?
}

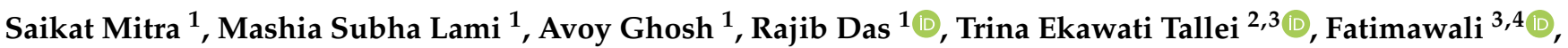 \\ Fahadul Islam ${ }^{5}$, Kuldeep Dhama ${ }^{6}{ }^{(0)}$, M. Yasmin Begum ${ }^{7}$, Afaf Aldahish ${ }^{8}{ }^{(0)}$, Kumarappan Chidambaram ${ }^{8}$ \\ and Talha Bin Emran $9, * \mathbb{D}$
}

Citation: Mitra, S.; Lami, M.S.; Ghosh, A.; Das, R.; Tallei, T.E.; Fatimawali; Islam, F.; Dhama, K.; Begum, M.Y.; Aldahish, A.; et al. Hormonal Therapy for Gynecological Cancers: How Far Has Science Progressed toward Clinical Applications?. Cancers 2022, 14, 759. https://doi.org/10.3390/ cancers14030759

Academic Editors: Simon Langdon and Charlie Gourley

Received: 30 November 2021

Accepted: 30 January 2022

Published: 1 February 2022

Publisher's Note: MDPI stays neutral with regard to jurisdictional claims in published maps and institutional affiliations.

Copyright: (C) 2022 by the authors. Licensee MDPI, Basel, Switzerland. This article is an open access article distributed under the terms and conditions of the Creative Commons Attribution (CC BY) license (https:// creativecommons.org/licenses/by/ $4.0 /)$.
1 Department of Pharmacy, Faculty of Pharmacy, University of Dhaka, Dhaka 1000, Bangladesh; saikat-2018926336@pharmacy.du.ac.bd (S.M.); mashiasubha-2018526349@pharmacy.du.ac.bd (M.S.L.); avoy-2018626384@pharmacy.du.ac.bd (A.G.); rajib-2016714522@pharmacy.du.ac.bd (R.D.)

2 Department of Biology, Faculty of Mathematics and Natural Sciences, Sam Ratulangi University, Manado 95115, Indonesia; trina_tallei@unsrat.ac.id

3 The University Center of Excellence for Biotechnology and Conservation of Wallacea, Institute for Research and Community Services, Sam Ratulangi University, Manado 95115, Indonesia; fatimawali@unsrat.ac.id

4 Pharmacy Study Program, Faculty of Mathematics and Natural Sciences, Sam Ratulangi University, Manado 95115, Indonesia

5 Department of Pharmacy, Faculty of Allied Health of Sciences, Daffodil International University, Dhaka 1207, Bangladesh; fahadul29-774@diu.edu.bd

6 Division of Pathology, ICAR-Indian Veterinary Research Institute, Izatnagar, Bareilly 243122, Uttar Pradesh, India; kdhama@rediffmail.com

7 Department of Pharmaceutics, College of Pharmacy, King Khalid University, Abha 61441, Saudi Arabia; ybajen@kku.edu.sa

8 Department of Pharmacology and Toxicology, College of Pharmacy, King Khalid University, Abha 62529, Saudi Arabia; adahesh@kku.edu.sa (A.A.); kumarappan@kku.edu.sa (K.C.)

9 Department of Pharmacy, BGC Trust University Bangladesh, Chittagong 4381, Bangladesh

* Correspondence: talhabmb@bgctub.ac.bd; Tel.: +880-1819-942214

Simple Summary: The most common therapies for severe and recurrent gynecological cancers are hormone therapy and chemotherapy, and responsiveness to therapy is a key component in prognosis and survivability. Hormone therapy has recently been demonstrated to be an excellent cancer treatment approach. Hormone treatment for gynecological cancers is taking drugs that decrease hormone levels or impede their biological activity, halting or slowing cancer progression. Hormone therapy works by suppressing the multiplication of cancer cells triggered by hormones. Hormonal therapy, such as progestogens or tamoxifen, is frequently recommended for patients with hormonesensitive recurrent or metastatic gynecological cancers, but response rates and therapeutic effects are inconsistent. Therefore, we discuss the pathogenesis of gynecological malignancies from the hormonal landscape and the use of hormonal therapies toward clinical applications.

\footnotetext{
Abstract: In recent years, hormone therapy has been shown to be a remarkable treatment option for cancer. Hormone treatment for gynecological cancers involves the use of medications that reduce the level of hormones or inhibit their biological activity, thereby stopping or slowing cancer growth. Hormone treatment works by preventing hormones from causing cancer cells to multiply. Aromatase inhibitors, anti-estrogens, progestin, estrogen receptor (ER) antagonists, GnRH agonists, and progestogen are effectively used as therapeutics for vulvar cancer, cervical cancer, vaginal cancer, uterine cancer, and ovarian cancer. Hormone replacement therapy has a high success rate. In particular, progestogen and estrogen replacement are associated with a decreased incidence of gynecological cancers in women infected with human papillomavirus (HPV). The activation of estrogen via the transcriptional functionality of ER $\alpha$ may either be promoted or decreased by gene products of HPV. Hormonal treatment is frequently administered to patients with hormone-sensitive recurring or metastatic gynecologic malignancies, although response rates and therapeutic outcomes are inconsistent. Therefore, this review outlines the use of hormonal therapy for gynecological cancers and identifies the current knowledge gaps.
} 
Keywords: hormonal therapy; gynecological cancers; aromatase inhibitors; anti-estrogen; GnRH agonist

\section{Introduction}

Cancer is a leading cause of death worldwide. Gynecological cancers are the most prevalent cancer in women. Cervical cancer is the most common type of gynecological cancer [1]. Gynecological cancer refers to any cancer that develops in a woman's reproductive organs. Gynecological cancers can start anywhere in a woman's pelvis, the area beneath her stomach, and between her hip bones [2]. Cervical cancer, vulvar cancer, vaginal cancer, uterine cancer, and ovarian cancer are the five categories of gynecological cancer. The cervix, the lower and narrow end of uterus, is where cervical cancer develops [3]. The developing world bears a disproportionately high burden of cervical cancer, accounting for $85 \%$ of the approximately 493,000 new cases and 273,000 deaths annually. Cervical cancer is an issue in areas where most people are underprivileged and women's socioeconomic position is low, and ethnicity can also be a risk factor [4]. Cervical cancer is the fourth most common cancer in women and the fourth leading cause of cancer deaths. Premalignant cervical intraepithelial neoplasia (CIN) precedes cervical cancer. CINs (CIN1, CIN2, CIN3) can be efficiently cured by uncomplicated surgery, but they carry a risk of future pregnancy problems [5]. Ovarian cancer is the most common cause of mortality from gynecological cancer. Around $70 \%$ of patients who have ovarian cancer are diagnosed at stage III/IV and $75 \%$ of these cases deteriorate within two years of first-line therapy, making it unlikely that they will be cured. Though salvage chemotherapy for recurrent cancer can produce objective tumor responses, it does not always result in longer progression-free or overall survival [6,7]. Ovarian cancer is believed to be influenced by the pituitary gonadotropins follicle-stimulating hormone (FSH) and luteinizing hormone (LH), and by progesterone, androgens, IGF-I, and estrogens [8].

Uterine cancer, also known as endometrial cancer, starts in the uterus, in the layer of cells that make up the uterus lining (endometrium) [9]. Endometrial cancer is the sixth most prevalent cancer in women and the fifteenth most common cancer in the general population. In 2018, there were around 380,000 new cases [10]. Vaginal cancer has five subtypes: sarcomas, squamous cell carcinoma, clear cell adenocarcinoma, adenocarcinoma, and melanoma [11]. The 5-year survival rate for women with vaginal cancer is $49 \%$. If the cancer is diagnosed early, prior to spreading outside of the vaginal wall, the 5-year survival rate is $66 \%$ [12]. Another type of gynecological cancer is vulvar cancer, which begins in the vulva. Patients with vulvar cancer have a 5-year survival rate of around $70 \%$ [13].

Hormone therapy and chemotherapy are the most common treatments for severe and recurrent gynecological malignancies, and responsiveness to therapy is a critical factor affecting prognosis and survival. Hormone therapy has become more frequently used in recent years as a result of the harsh side effects of chemotherapy. Hormone treatment for cancer involves taking medications that inhibit the biological activity or reduce the level of hormones in order to prevent or reduce cancer growth. Hormone therapy either inhibits the production of hormones or stops hormones from causing cancer cells to multiply and divide. However, it is not effective against all cancers [14]. The treatment of patients with gynecological cancers has advanced significantly in recent years [15].

The goal of this study was to convey the current state of gynecological cancer research, with a focus on hormone therapy. Extensive literature searches and reviews were conducted in order to determine the pathogenesis and possible therapy of hormones. The aim of this review is to understand the use of hormones in the treatment of gynecological cancers.

\section{Pathogenesis of Gynecological Cancers: Hormonal Landscape}

\subsection{Cervical Cancer}

Chronic infection with oncogenic HPV strains is the most important etiological factor in the development of cervical cancer. The production of two viral oncoproteins, E7 and 
E6, in parabasal or basal cells, can trigger and maintain neoplastic development [16]. In pre-invasive squamous cell carcinoma of the cervix, defective cells are restricted to the epithelium. Cervical intraepithelial neoplasia (CIN) is a noninvasive disorder that is linked to HPV integration and infection. CIN progresses from early modifications involving the deeper layers of the epithelium (CIN1) to later stages involving the entire epithelium (CIN3), which equates to squamous cell carcinoma (Figure 1) [17]. Cervical adenocarcinoma is a malignant neoplasm involving the cervical glandular epithelium. Adenocarcinoma exists in a variety of forms; the majority of these have identical etiology and risk factors to squamous cell carcinoma. Seventy percent of adenocarcinomas are endocervical-type mucinous adenocarcinomas [18,19].

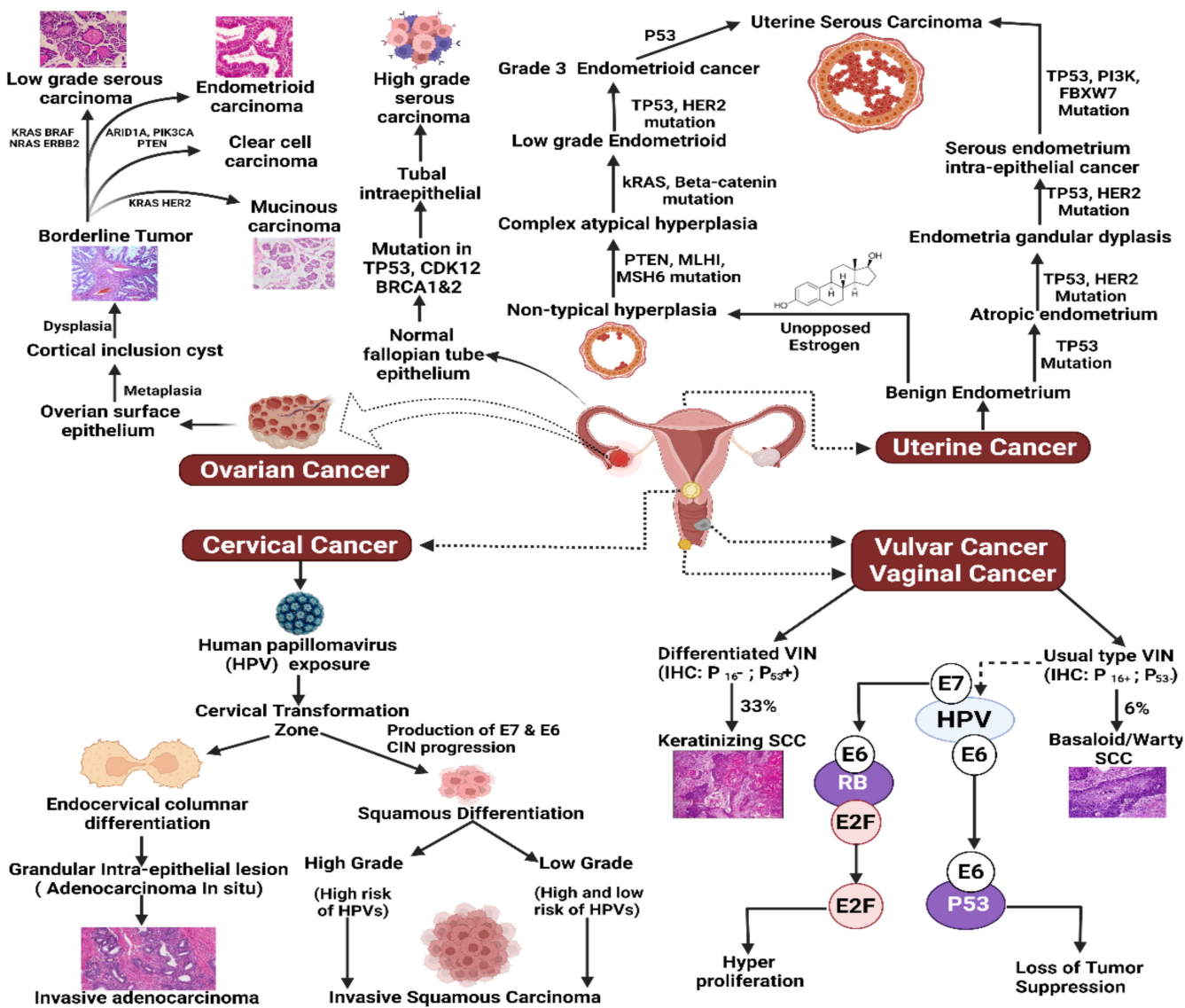

Figure 1. Pathogenesis of gynecological cancers. Ovarian: Borderline tumors can form from the ovarian surface epithelium and can develop into low grade serous, endometrioid, clear cell, and mucinous carcinoma by mutation and alteration of certain genes, e.g., KRAS, BRAF, NRAS, HER2, CTNNB1, BRAF, ERBB2, ARID1A, PIK3CA, PTEN, HER2, etc. High-grade serous carcinoma is developed from normal fallopian tube epithelium by the mutation of TP53, CDK12, BRCA1 and 2. Uterine: Uterine cancer result from TP53, HER2, PI3K, FBXW7, KRAS, PTEN, MLHI, MSH6, Betacatenin mutation, and CTNNBI alteration. Vulvar: (uVIN: E6 degrades the tumor suppressor p53; E7 inactivates the tumor suppressor RB and releases E2F resulting in hyperproliferation.) (dVIN: Chronic dermatoses, especially Lichen sclerosus and Lichen planus, can progress to dVIN and SCC), (VIN, vulvar intraepithelial neoplasia). Vaginal: TP53 gene alteration and HPV 16 and 18, etc., are the importance carcinogenic factors for both HPV-dependent or -independent vaginal cancer. Cervical: Production of E7 and E6, infection with HPV, CIN progression cause differentiation in squamous cervical cells and cause invasive adenocarcinoma.

Squamous cell carcinoma is the more prevalent type of cervical cancer. The most prevalent cause of cervical cancer, HPV, has a glucocorticoid/progesterone response element upstream of the common E7/E6 promoter, and progesterone increases the viral DNA's ca- 
pacity to transform cells [20-22]. Papillomavirus lesions are aggravated through pregnancy when progesterone levels are high, and oral contraceptives containing progestogen are a risk factor for cervical cancer development in HPV-positive individuals. Estrogen activates human HPV development by upregulating progesterone receptors [22,23]. Although the relationship between estradiol (E2) replacement or selective ER modulator (SERM) treatment and cervical cancer is contentious [24], the E2-ER $\alpha$ and progesterone-progesterone receptor (P4-PR) signaling pathways may be implicated in the progression and/or development of cervical cancer. PR is a ligand-dependent therapeutic target for cervical cancer, much as it is for endometrial cancer. While PR was produced in $100 \%$ of cervical malignancies in a mouse model, it is produced in only $20-40 \%$ of human cervical malignancies $[25,26]$. Estrogen promotes the growth of E6 and E7 oncogenes, which are thought to be the primary causes of cervical cancer. Furthermore, ER $\alpha$ and estrogen are essential for cervical carcinogenesis, while SERMs suppress cervical cancer in HPV-associated cervical cancer mouse models [27]. Estrogens stimulate cervical carcinogenesis, while progesterone prevents it, according to data from HPV transgenic mouse models [27,28].

\subsection{Ovarian Cancer}

The World Health Organization (WHO) histological classification of ovarian cancers is based on histogenetic principles, and this classification categorizes ovarian tumors based on their derivation from coelomic surface epithelial cells, germ cells, and mesenchyme (the stroma and the sex cord). The bulk of malignant ovarian tumors are epithelial ovarian tumors, which are further classified into histological types as follows: carcinosarcoma, mixed epithelial tumor, undifferentiated carcinoma, and others are examples of serous, mucinous, endometrioid, clear cell, transitional cell cancers (Brenner tumors), and others [29]. The most prevalent subtype of ovarian cancer is ovarian serous carcinoma. It manifests as either low-grade ( $10 \%$ of all serous subtype tumors) or high-grade carcinoma ( $90 \%$ of all the serous subtype tumors) [30]. Non-epithelial ovarian cancers are a rare but intriguing type of malignancies that can be particularly difficult to treat due to their non-epithelial nature. These tumors account for just $10-15 \%$ of all ovarian malignancies when taken as a whole, and they may arise at any age, from infancy to old age. As a general phrase, this covers a variety of tumors originating from germ cells, sex cord stromal cells, and other forms of ovarian cancer that are exceedingly uncommon, including small-cell carcinomas and sarcomas [31]. Conversely, epithelial ovarian tumors can be type I or type II. Examples of type I epithelial tumors, which grow slowly, are clear cell carcinomas, endometrioid, and low-grade micropapillary serous carcinomas. Examples of type II epithelial tumors include high-grade serous carcinoma, undifferentiated carcinoma, and carcinosarcoma. Borderline tumors begin as ovarian surface epithelium and progress to low-grade serous, endometrioid, clear cell, and mucinous carcinomas by mutation and change of certain genes such as KRAS, BRAF, NRAS, HER2, CTNNB1, BRAF, ERBB2, ARID1A, PIK3CA, PTEN, HER2, and others. In high-grade serous tumors, high-grade serous cancers that arise from normal fallopian tube epithelium by mutations in TP53 or BRCA1, BRCA2, MLH1, or MSH2 are thought to be the cause. [32]. Instead of traditional metastasis through the hematogenous pathway, ovarian cancers metastasize through the peritoneal circulation, which is involved in the formation of ascites [33].

CA-125 is the most well-known ovarian cancer biomarker. It is a high-molecularweight transmembrane glycoprotein that is expressed by coelomic- and Müllerian-derived epithelia, such as those in the fallopian tube, endometrium, and endocervix [34]. Gene expression in ovarian cancer shows both how the cancer looks and how it behaves. Clear cell ovarian cancer is different from other cancers that have a poor prognosis because of this [35]. The most important thing about any tumor is the combination of genetic changes that make it grow and make it spread. In this area, ovarian tumors show a lot of different types. These types of tumors usually have changes in a lot of different genes, such as KRAS, BRAF, PTEN, TFG-R, and $\beta$-catenin [36]. Following the implantation of ovarian cancer cells, the resulting inflammation causes the release of cytokines such as interleukin (IL)-1, -8 , 
and -6 by peritoneal cells and their associated stromal and immune cells, which drive tumor angiogenesis and ascites formation by enhancing tumor cell VEGF secretion [37]. In spite of their variations, each of these ovarian cancer metastatic processes are essentially driven by cell migration, involving cycles of cell adhesion, actin polymerization, and actomyosin contraction [38]. Furthermore, ovarian cancer cells undergo epithelial-mesenchymal transition driven by ROCK/Rho signaling (Figure 1) [37].

Microfibrillar-associated protein 5 stimulates ovarian cancer motility and metastatic potential via the $\mathrm{Ca}^{2+}$-dependent focal adhesion kinase/cAMP response element-binding protein/troponin $C$ type 1 signaling pathway [39]. Versican is a major upregulated gene in CAFs that enhances ovarian cancer cell motility and invasion by activating NF- $\mathrm{B}$ and upregulating the expression of MMP-9, CD44, and hyaluronan-mediated motility receptors in cancer cells $[40,41]$. The c-myc oncogene and HER-2/neu are amplified and overexpressed in 20-30\% of epithelial ovarian cancers [42].

Hormone treatment employs the use of prescription medications to prevent or reduce the action of hormones such as estrogen. This is significant because certain types of ovarian cancer cells require those hormones to thrive and spread in the body [43]. Exaggerated stimulation of ovarian tissues by the pituitary gonadotropins follicle-stimulating hormone (FSH) and luteinizing hormone (LH) leads to ovarian cancer [44]. The longer a woman is subjected to estrogen, the greater her vulnerability to ovarian cancer is predicted to be. Because large amounts of estrogen are only present throughout a woman's reproductive years, the longer she menstruates, the greater her risk. Childbearing can minimize risk by giving a woman nine-month "rests" from ovulation during pregnancy, lowering her total estrogen exposure. When taken for more than three cycles, the medications clomiphene citrate and pergonal, which are routinely used to treat infertility, appear to raise the risk of ovarian cancer [45].

\subsection{Uterine and Endometrial Cancer}

Uterine sarcoma, uterine carcinosarcoma, uterine clear cell carcinoma, and uterine papillary serous carcinoma are the most prevalent uterine and endometrial cancers. Uterine cancer has four stages: stage I, in which the cancer is confined to the uterus, stage 2, in which it has progressed to the cervix, stage III, in which the cancer has migrated to the vaginal canal, the lymph nodes, or the ovaries, and stage IV, in which the cancer has spread to the rectum or bladder, or organs other than the uterus, such as the lungs or bones [46].

Endometrial cancer develops when normal endometrial cell development is disrupted. Endometrial hyperplasia (overgrowth of endometrial cells) is a risk for adenocarcinoma since hyperplasia can and often does progress to adenocarcinoma; however, cancer can occur in the absence of hyperplasia [47]. This arises from endometrial hyperplasia brought on by uncontrolled estrogenic stimulation, and involves the production of progesterone and estrogen receptors by the estrogen passageway. There are two types of endometrial carcinoma, estrogen-dependent (type I) or estrogen-independent (type II). Clinical studies indicate that type I carcinomas are associated with low risk of lymph node metastasis, favorable prognosis, early cancer stage at diagnosis, and minimal myometrial invasion, whereas type II carcinomas are associated with high risk of lymph node metastasis, poor prognosis, advanced cancer stage at diagnosis, and deep myometrial invasion (Figure 1) [48].

The cancer usually progresses to the serosa and myometrium initially, before progressing to other pelvic and reproductive structures. Whenever the lymphatic system is involved, the para-aortic and pelvic lymph nodes are typically the first to be affected, however, unlike in cervical cancer, there is no specific pattern [49]. Endometrial cancer development is influenced by genes of grade 3. Mutations in a tumor suppressor gene, usually PTEN or TP53, are common. PTEN has a loss-of-function or null mutation in $50 \%$ of endometrioid malignancies and $20 \%$ of endometrial hyperplasias, making the PTEN protein either less efficient or completely inactive [50]. The mTOR/PI3K pathway is upregulated when PTEN function is lost, which drives cell proliferation. In endometrial cancers, the TP53 pathway 
can either be repressed or highly active. Overexpression of a mutant form of TP53 causes endometrial cancers to become more aggressive (Figure 1) [51].

Loss of function mutations to $\mathrm{p} 27$ and PTEN are linked to a favorable prognosis. In $20 \%$ of serous and endometrioid carcinomas, the oncogene Her $2 /$ neu is amplified or overexpressed. Mutations in CTNNB1 (encoding the $\beta$-catenin protein) are identified in $14-44 \%$ of endometrial malignancies and may suggest a favorable prognosis. In almost all endometrial cancers involving squamous cells, CTNNB1 alterations are present [51]. Although FGFR2 alterations are present in about $10 \%$ of endometrial malignancies, their impact on prognosis is unknown [50]. SPOP is another tumor suppressor gene that was reported to be mutated in $8 \%$ of serous endometrial carcinomas and $9 \%$ of clear cell endometrial carcinomas [52].

Distinct mutations are associated with type I and II malignancies. ARID1A, which often carries a point mutation in type I endometrial cancer, is also mutated in approximately $26 \%$ of endometrial clear cell carcinomas and $18 \%$ of serous carcinomas [53]. In both type I and II malignancies, PIK3CA is frequently mutated [51]. KRAS is also often mutated [54].

Gonadotropin-releasing hormone analog $(\mathrm{GnRHa})$ was able to inhibit ovarian cancer cell growth by increasing inositol phosphate levels and initiating protein kinase pathways such as ERK1/2, and also to stimulate ovarian cancer cell apoptosis by increasing expression of apoptosis-associated genes and stimulating the Fas system [55]. Inadequate progesterone leads to unregulated estrogen activity, which can lead to adenocarcinoma and endometrial hyperplasia [56].

\subsection{Vaginal Cancer}

Vaginal cancer is a clinically diverse disease. Although HPV is a common cause of vaginal tumors, there are also carcinogenic mechanisms which are HPV-independent [57]. There are varying stages of histologic differentiation in vaginal cancer: invasive cancer, potential microinvasive carcinoma, carcinoma in situ, and vaginal intraepithelial neoplasia (VAIN) (from least to most malignant) [18,58]. TP53 gene alterations are the principal carcinogenic factor in vulvar cancer and HPV 18 and 16 have a prevalent role in cervical cancer, whereas vaginal cancer can be caused by either (Figure 1) [59].

Radiation carcinogenesis is a third explanation for the link between vulva or cervix carcinoma and vaginal cancer [60]. The mechanism by which DES may contribute to the development of clear cell adenocarcinoma is unknown [61]. In a study of estrogeninduced maturation arrest of the Müllerian ducts, Robboy et al. proposed in 1984 that atypical cervical ectropion of the tuboendometrial type and atypical vaginal adenosis may be precursors to clear cell cancer of the vagina and cervix [62]. Postmenopausal women who use vaginal estrogen are at the same risk as women who do not use vaginal estrogen for invasive breast cancer, stroke, blood clots, endometrial cancer, and colorectal cancer [63].

\subsection{Vulvar Cancer}

Two distinct mechanisms lead to the development of vulvar cancer [64]. The occurrence of lichen sclerosis and differentiated vulvar intraepithelial neoplasia (dVIN) is one factor. This accounts for around $80 \%$ of vulvar cancers [65]. dVIN lesions and vulvar squamous cell carcinomas carry the same TP53 mutations. The second form tends to affect teenagers who have been infected with high-risk HPV, most commonly HPV 16. The percentage of vulvar malignancies linked to HPV varies significantly between populations, spanning from $15-79 \%$. Impaired DNA repair, variations in active repopulation signaling passageways, as well as impaired cell cycle regulation are also possible underlying causes [66].

EGFR is a transmembrane-receptor tyrosine kinase. When a ligand binds to EGFR, the receptor is autophosphorylated on tyrosine residues, activating a number of intracellular channels that can lead to cancer cell proliferation, metastasis, invasion, and promotion of tumor-induced neovascularization [67]. EGFR overexpression has been reported in $46-72 \%$ of patients with vulvar cancer [68]. A negative correlation between HPV status 
and EGFR amplification suggests that EGFR copy number increases play a role in vulvar carcinogenesis independent of HPV [69].

Angiogenesis is a critical step in tumor formation and metastatic spread. One of the most important controllers of this mechanism is the VEGF pathway [70]. In the case of vulvar cancer, VEGF overexpression is associated with high mortality and poor tumor distinction [71,72]. In VIN lesions, increased expression had also been reported, alongside VIN3 expressing much more than VIN1 and VIN2 (Figure 1) [73]. Vulvar cancers are rarely hormone-dependent tumors [74]. HRT is impartial in endometrial cancer type II, uterine carcinosarcoma, and adenosarcoma, some forms of ovarian cancer, cervical, vaginal, and vulvar squamous cell carcinoma, prolactinoma, kidney cancer, pancreatic cancer, and thyroid cancer [63]. However, tissue-selective estrogen complex incorporating BZA/CE is a possible menopause therapy for postmenopausal women [75].

\section{Hormonal Therapy for Gynecological Cancers}

\subsection{Hormonal Therapy for Cervical Cancer}

Hormonal therapy for cervical cancer has been reported in a variety of experimental and clinical investigations. Sawaya et al. reported that medroxyprogesterone acetate at a dose of $2.5 \mathrm{mg} /$ day and oral conjugated equine estrogens at $0.625 \mathrm{mg} /$ day were administered to 2561 women for two years. This study determined the predictive value of an abnormal cervical smear in postmenopausal women with recent normal smears. In the two years after a normal smear, the rate of new cytologic abnormalities was 110 per 4895 person-years ( 23 per 1000 person-years ( $95 \%$ CI, 18 to 27 per 1000 person years)). There was one case of mild to moderate dysplasia among the 103 women with documented histological diagnosis. The positive predictive value of any smear abnormality identified 1 year after a normal smear, therefore, was $0 \%$ (CI, $0 \%$ to $5.0 \%$ ) (0 of 78 women); the positive predictive value of abnormalities found within 2 years was $0.9 \%$ (CI, $0.0 \%$ to $3.0 \%$ ) ( 1 of 110 women). The findings concluded that the prevalence of cytologic abnormalities was non-significantly greater in hormone-treated women than in women who were not treated with hormone [76]. In postmenopausal women undergoing hormone replacement therapy (HRT), several studies found a significantly lower risk of cervical squamous cell carcinoma and a slight increase in the risk of adenocarcinoma. There are no indications that HRT has a negative effect on the oncological outcome of CC, and numerous advantages have been reported, such as improvement in quality of life and decreased metabolic risk, leading to the conclusion that HRT should be provided to young survivors of CC for the management of early menopause [77]. In another clinical trial, 645 women with cervical cancer aged 40-75 years were medicated with estrogen replacement therapy (ERT) and followed for ten years. The odds ratio was 0.9 (95\% CI: 0.5-1.7). The odds ratios for cervical cancer decreased with duration of therapy when compared to a control group, decreasing to 0.6 (95\% CI: 0.4-1.1) for timespans shorter than 12 months and 0.5 (95\% CI: 0.2-1.0) for timespans of 12 months or longer. These results indicate that exogenous estrogens may reduce the incidence of cervical cancer [78]. K14E7 and K14E6 transgenic mice were treated with $0.15 \mathrm{~mL}$ of the ER antagonist Faslodex twice a week for one month, and $1.5 \mathrm{mg}$ of raloxifene 5 days a week for one month. In this study, raloxifene, an ER antagonist and selective ER modulator, effectively cleared cancer and precursor lesions in both the vagina and the cervix [79]. The combination of synthetic estrogen and synthetic progestogen is effective in treating cervical cancer. After radiotherapy or surgery for stage I or II cervical cancer, 120 patients received $2 \mathrm{mg}$ chlormadinone and $5 \mathrm{mg}$ dienestrol daily for five years. The occurrence of cancer relapse was $20 \%$ in the group that underwent hormone treatment [80]. Hormonal therapy (HT) consisting of progesterone, estrogen, or progesterone and estrogen together was applied in 804 CIN3/CIS cases in peri- and postmenopausal women and 261 invasive cervical cancer (ICC) cases in three distinct groups of women who received treatment for different time periods, $\leq 1,2-4$, and $\geq 5$ years. The therapy was found to be associated with a lower risk of ICC (HR $=0.5,95 \%$ CI: 0.4-0.8). The use of HT by peri- and postmenopausal women reduced the risk of ICC substantially. 
However, estrogen alone was associated with a higher incidence of CIN3/CIS, whereas coupled HT was associated with a lower incidence of ICC [81].

Certain cervical cancers may respond in a hormone-independent manner to a combination treatment consisting of triphenylethylene and the antiestrogen medication tamoxifen. Roig et al. conducted an experiment on 19 patients with invasive cervical cancer and found that tamoxifen treatment for 10 days at 20 or $40 \mathrm{mg} /$ day resulted in alterations in growth and distinction levels in some cervical carcinomas [82]. Another study by L. Bigler found that $10 \mathrm{mg}$ of the antiestrogen medication tamoxifen taken twice a day orally in 34 non-squamous cell carcinoma patients with median age of 49 had an objective response rate of $11.1 \%$ [83]. Another trial studied the use of progestagen mixed oral contraceptives in 16,573 women who had cervical cancer and 35,509 who did not. The cohort was split into groups that had used progestagen for fewer than five years, and groups that had used progestagen for more than five years. The risk of cervical cancer was increased in the groups with over five years progestagen use [84]. Progesterone, estradiol, and estrone are essential hormones that are utilized as treatments for cervical cancer. In one study, 11,742 women aged over 18 were subjected to HT, including progesterone $\left(100 \mathrm{pg} \cdot \mathrm{mL}^{-1}\right)$, oestrone $\left(5 \mathrm{pg} \cdot \mathrm{mL}^{-1}\right)$, SHBG $\left(20 \mathrm{nmol} \mathrm{L}{ }^{-1}\right)$, oestrone sulphate $\left(100 \mathrm{pg} \cdot \mathrm{mL}^{-1}\right)$, estradiol $\left(5 \mathrm{pg} \cdot \mathrm{mL}^{-1}\right)$, and DHEAS $\left(10 \mu \mathrm{g} \cdot \mathrm{dL}^{-1}\right)$. After observation for $5-10$ years, it was found that increased plasma levels of progesterone or endogenous estrogens reduced the incidence of cervical neoplasia (Figure 2) [85].
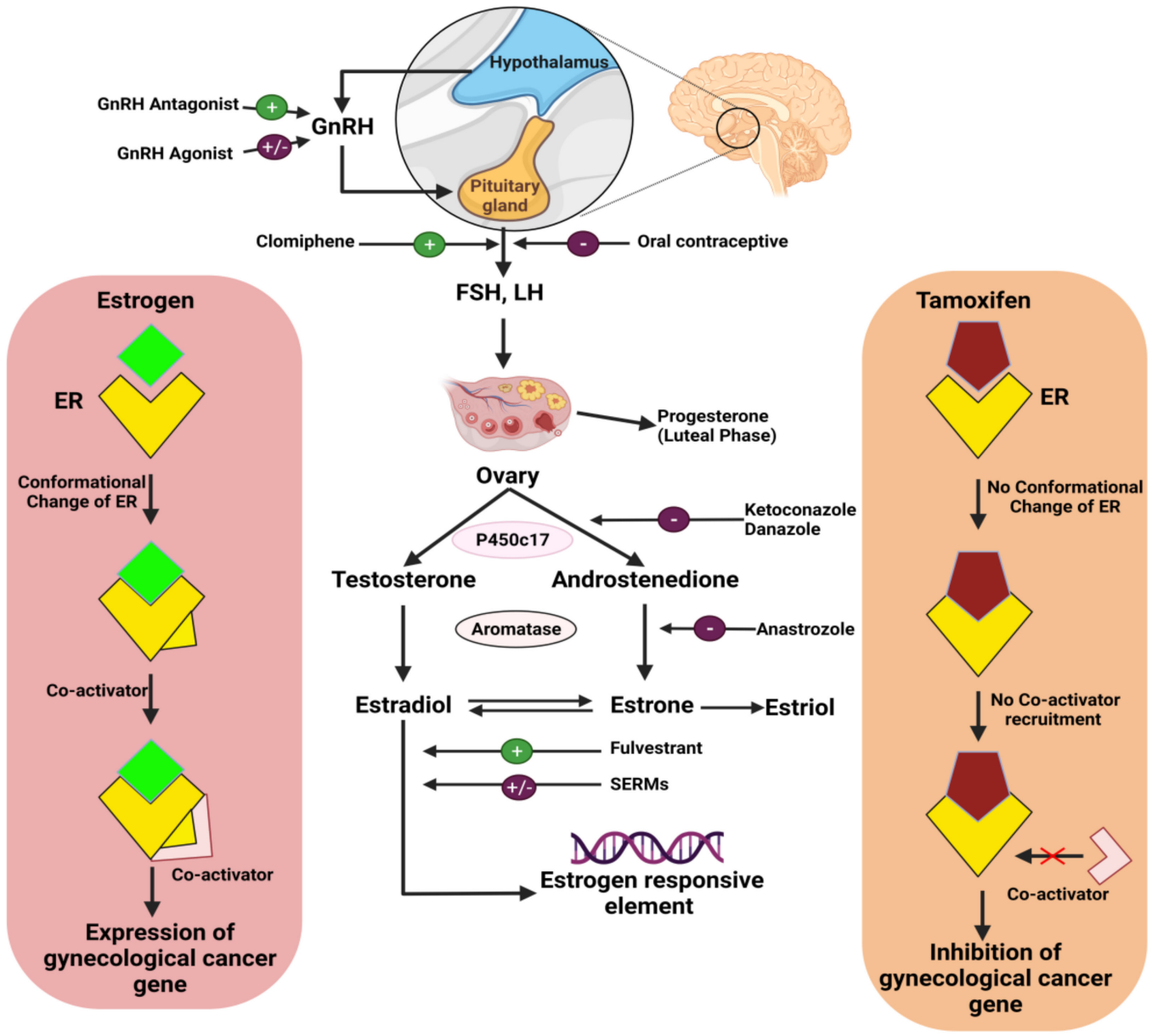

Figure 2. Hormonal therapies to counter gynecological cancer progression.

Pannoneon and Rauh conducted a clinical trial including 222 women. After treatment for cervical cancer, $48 \%$ of patients received HRT counseling and efforts to decrease inequities in the provision of survivorship care were enhanced (Table 1) [86]. Tamoxifen at 0 , 
$1,2.5,5,7.5$, or $10 \mu \mathrm{M}$ for a time span of 6 days suppressed the in vitro proliferation of three cervical carcinoma cell lines generated from uterine cervical carcinoma (ME-180, CaSki, and HeLa). Progressive cell death and cytotoxicity were found at doses greater than $5 \mu \mathrm{M}$. A dose of $2.5 \mu \mathrm{M}$ tamoxifen inhibited development by more than $60 \%$ in the CaSki cell line, while $5 \mu \mathrm{M}$ tamoxifen was cytotoxic [87].

Table 1. Experimental and clinical studies of hormonal therapy to treat cervical cancer.

\begin{tabular}{|c|c|c|c|c|c|}
\hline $\begin{array}{l}\text { Name of } \\
\text { Hormone }\end{array}$ & $\begin{array}{c}\text { Formulation } \\
\text { Name and Dose }\end{array}$ & Observation Time & Study Model & Results & References \\
\hline ER antagonist & $\begin{array}{l}0.15 \mathrm{~mL} \text { Faslodex } \\
\text { and } 1.5 \mathrm{mg} \text { of } \\
\text { raloxifene }\end{array}$ & $\begin{array}{l}\text { Faslodex twice a } \\
\text { week for a month } \\
\text { and raloxifene for } \\
\text { a month, } 5 \text { days a } \\
\text { week }\end{array}$ & $\begin{array}{l}\text { K14E7 and K14E6 } \\
\text { transgenic mice }\end{array}$ & $\begin{array}{l}\text { Raloxifene, ER antagonist } \\
\text { and selective ER modulator, } \\
\text { efficiently clears cancer and } \\
\text { its precursor lesions in both } \\
\text { the cervix and the vagina }\end{array}$ & [79] \\
\hline $\begin{array}{l}\text { Non-steroid } \\
\text { synthetic } \\
\text { estrogen with } \\
\text { synthetic } \\
\text { progestagen }\end{array}$ & $\begin{array}{l}\text { Dienestrol-1 } \\
\text { tablet }(5 \mathrm{mg}) \text { and } \\
\text { Chlormadinon-1 } \\
\text { tablet }(2 \mathrm{mg})\end{array}$ & 5 years & $\begin{array}{l}120 \text { patients after } \\
\text { surgery and/or } \\
\text { radiotherapy }\end{array}$ & $\begin{array}{l}\text { Only } 20 \% \text { and } 32 \% \\
\text { incidence of cancer } \\
\text { recurrences and survival } \\
\text { without cancer symptoms } \\
\text { was found in } 80 \% \text { and } 65 \% \\
\text { of cases, respectively in the } \\
\text { hormonally treated group } \\
\text { and in the control group }\end{array}$ & [90] \\
\hline $\begin{array}{l}\text { Estrogen and } \\
\text { progesterone }\end{array}$ & $\begin{array}{l}\text { HT formulation } \\
\text { (estrogen alone, } \\
\text { progesterone alone, } \\
\text { combination of } \\
\text { estro- } \\
\text { gen/progesterone) }\end{array}$ & $\begin{array}{l}3 \text { groups }(\leq 1,2-4 \\
\geq 5 \text { years })\end{array}$ & $\begin{array}{c}261 \text { ICC and } 804 \\
\text { CIN3/CIS cases of } \\
\text { post- and } \\
\text { perimenopausal } \\
\text { women }\end{array}$ & $\begin{array}{l}\text { Significantly decreased the } \\
\text { risk of ICC in peri- and } \\
\text { postmenopausal women, } \\
\text { but menopausal estrogens } \\
\text { alone were associated with } \\
\text { an increased risk of } \\
\text { CIN3/CIS and combined } \\
\text { HT was inversely associated } \\
\text { with ICC }\end{array}$ & [81] \\
\hline ERT & - & $1-10$ years & 645 women & $\begin{array}{l}\text { Exogenous estrogens } \\
\text { decreased the risk of } \\
\text { cervical cancer }\end{array}$ & [78] \\
\hline $\begin{array}{l}\text { Estrogens } \\
\text { progestin }\end{array}$ & $\begin{array}{c}\text { Oral conjugated } \\
\text { equine estrogens, } \\
0.625 \mathrm{mg} / \text { day, plus } \\
\text { medroxyproges- } \\
\text { terone acetate, } 2.5 \\
\mathrm{mg} / \text { day }\end{array}$ & 2 years & 2561 women & $\begin{array}{c}\text { Did not significantly affect } \\
\text { the incidence of cytologic } \\
\text { abnormalities }\end{array}$ & [76] \\
\hline Anti-estrogen & $\begin{array}{l}\text { Triphenylethylene } \\
\text { antiestrogen } \\
\text { tamoxifen }\end{array}$ & $\begin{array}{c}10 \text { days ( } 20 \text { or } 40 \\
\mathrm{mg} / \text { day })\end{array}$ & 19 patients & $\begin{array}{l}\text { Certain cervical carcinomas } \\
\text { had changes in their } \\
\text { proliferation and } \\
\text { differentiation levels } \\
\text { following tamoxifen } \\
\text { administration }\end{array}$ & [82] \\
\hline Anti-estrogen & Tamoxifen & $\begin{array}{l}10 \text { mg per orally } \\
\text { twice a day }\end{array}$ & 34 patients & $\begin{array}{l}\text { The objective response rate } \\
\text { was } 11.1 \% \text {, so tamoxifen } \\
\text { appears to have minimal } \\
\text { activity in non-squamous } \\
\text { cell carcinoma of the cervix }\end{array}$ & [83] \\
\hline Progestagen & $\begin{array}{l}\text { Combined oral } \\
\text { contraceptives }\end{array}$ & $\begin{array}{c}<5 \text { years and }>5 \\
\text { years }\end{array}$ & 16,573 women & $\begin{array}{l}\text { The risk of invasive cervical } \\
\text { cancer increased with } \\
\text { increasing duration of use, } \\
\text { not for short time use }\end{array}$ & [84] \\
\hline
\end{tabular}


Table 1. Cont.

\begin{tabular}{|c|c|c|c|c|c|}
\hline $\begin{array}{l}\text { Name of } \\
\text { Hormone }\end{array}$ & $\begin{array}{c}\text { Formulation } \\
\text { Name and Dose }\end{array}$ & Observation Time & Study Model & Results & References \\
\hline $\begin{array}{l}\text { Estrone, estradiol } \\
\text { and } \\
\text { progesterone }\end{array}$ & $\begin{array}{c}\text { SHBG } \\
\left(20 \mathrm{nmol} \cdot \mathrm{L}^{-1}\right) \\
\text { estradiol } \\
\left(5 \mathrm{pg} \cdot \mathrm{mL}^{-1}\right) \\
\text { estrone } \\
\left(5 \mathrm{pg} \cdot \mathrm{mL}^{-1}\right) \\
\text { estrone sulphate } \\
\left(100 \mathrm{pg} \cdot \mathrm{mL}^{-1}\right) \\
\text { DHEAS } 10 \mu \mathrm{\mu g} \cdot \mathrm{dl}^{-1} \\
\text { and progesterone } \\
100 \cdot \mathrm{pg} \cdot \mathrm{mL}^{-1}\end{array}$ & $5-10$ years of study & 11,742 women & $\begin{array}{l}\text { Elevated plasma levels of } \\
\text { endogenous estrogens or } \\
\text { progesterone decrease the } \\
\text { risk of cervical neoplasia }\end{array}$ & [85] \\
\hline HRT & - & $\begin{array}{c}1 \text { January, } 2005 \text { to } \\
31 \text { December } 31 \\
2015\end{array}$ & 222 women & $\begin{array}{l}48 \% \text { patients received } \\
\text { counseling for HRT and } \\
\text { then improved efforts to } \\
\text { reduce disparities in the } \\
\text { distribution of survivorship } \\
\text { care }\end{array}$ & [86] \\
\hline $\begin{array}{l}\text { ER modulator, } \\
\text { Tamoxifen }\end{array}$ & $\begin{array}{c}5 \% \\
\text { dextran-charcoal } \\
\text { treated fetal bovine } \\
\text { serum (D5) and } 0, \\
1,2.5,5,7.5 \text {, or } 10 \\
\mu \mathrm{M} \text { tamoxifen }\end{array}$ & 6 days & $\begin{array}{l}\text { In vitro growth of } \\
\text { three cell lines } \\
\text { derived from } \\
\text { carcinoma of the } \\
\text { uterine cervix } \\
\text { (HeLa, CaSki, } \\
\text { ME-180) }\end{array}$ & $\begin{array}{l}\text { Inhibited cell growth of the } \\
\text { cervical carcinoma cell lines; } \\
2.5 \mu \mathrm{M} \text { tamoxifen induced } \\
\text { more than } 60 \% \text { growth } \\
\text { inhibition where } 5 \mu \mathrm{M} \\
\text { tamoxifen was cytotoxic }\end{array}$ & [87] \\
\hline $\begin{array}{l}\text { Estrogens and } \\
\text { progestogens }\end{array}$ & $\begin{array}{l}\text { Contraceptives } \\
\text { (G03A), estrogens } \\
(\mathrm{G} 03 \mathrm{C}), \\
\text { progestogens } \\
\text { (G03D), and } \\
\text { progestogens and } \\
\text { estrogens in combi- } \\
\text { nation (G03F). }\end{array}$ & $\begin{array}{c}0.5 \text { to } 1 \text { year after } \\
\text { diagnosis }\end{array}$ & $\begin{array}{c}171(67 \%) \text { of } 257 \\
\text { women had at least } \\
\text { one dispensing of } \\
\text { HT (Hor- } \\
\text { monal Therapy) }\end{array}$ & $\begin{array}{l}\text { Fewer than half of cervical } \\
\text { cancer survivors with } \\
\text { therapy-induced early } \\
\text { menopause used HT }\end{array}$ & [88] \\
\hline Estradiol & $\begin{array}{l}30 \text { to } 35 \mu \mathrm{g} \\
\text { ethinylestradiol }\end{array}$ & From 1995 to 2014 & $\begin{array}{c}\text { women aged } \\
15 \text { to } 49\end{array}$ & $\begin{array}{l}\text { The risk pattern among any } \\
\text { hormonal and combined } \\
\text { contraceptive users } \\
\text { generally increased with } \\
\text { longer duration of use and } \\
\text { declined after stopping }\end{array}$ & [89] \\
\hline
\end{tabular}

Everhov reported that estrogens, contraceptives, progestogens, and estrogen-progestogen combination are potent treatments for cervical cancer. In their experiment it was found that $171(67 \%)$ of 257 women had at least one course of HT for half a year to a whole year after the diagnosis. Slightly less than half of cervical cancer survivors who had therapy-induced early menopause underwent HT at or close to the suggested dose while reducing the dosage over time. This implies that HT can be safely given to survivors of cervical cancer [88]. Nevertheless, a study of women aged 15-49 taking ethinylestradiol (30-35 $\mu$ g) between 1995 and 2014 reported that the risk of cervical cancer increased during ethinylestradiol usage and decreased after cessation [89].

\subsection{Hormonal Therapy for Ovarian Cancer}

Since the etiology of ovarian cancer is poorly understood, primary prevention efforts are difficult. According to a meta-analysis of data covering the years 1966-2006, postmenopausal use of HT increased the risk of ovarian cancer by $30 \%$, and estrogen therapy 
(ET) alone carried a higher risk than estrogen plus progestin therapy (EPT) [91]. Hormone treatment for ovarian cancer patients usually consists of a combination of medications that suppress estrogen levels in the body. Hormone treatment can also be used to raise progesterone levels, which might inhibit cancer cell growth in some circumstances [44]. The most common treatments for ovarian stromal tumors are hormone-inhibiting or hormone medications. Leuprolide and goserelin are two examples of LHRH agonists [92]. Tamoxifen is a drug that can be used to treat ovarian stromal tumors, but is only utilized in rare cases to manage advanced ovarian epithelial cancers. The purpose of tamoxifen therapy is to prevent endogenous estrogens from triggering cancer cell proliferation [93]. Exemestane, anastrozole, and letrozole are aromatase inhibitors that prevent estrogen synthesis. As they do not block ovarian estrogen production, they are only useful for reducing estrogen levels in postmenopausal women (Figure 2) [94].

According to the findings of a global randomized medical study, women who received estrogen hormone replacement treatment (HRT) following diagnosis with epithelial ovarian cancer survived longer than women who did not receive estrogen (Figure 2) [95]. The gonadotropin-releasing hormone analog leuprolide acetate $(1 \mathrm{mg})$ was administered to 23 patients with refractory epithelial ovarian cancer for a minimum of 8 weeks, providing evidence of antitumor activity against refractory grade 1 epithelial ovarian adenocarcinoma [96].

When used during CA125 relapses, the aromatase inhibitor letrozole can result in disease stability and CA125 responses, which are associated with increased ER expression. Sixty patients were given $2.5 \mathrm{mg}$ letrozole daily for 12 weeks, and the findings showed that future gynecological cancer investigations might focus on a group of endocrine-sensitive aromatase inhibitors [97]. Similarly, in a group of 27 patients, letrozole at a dosage of $2.5 \mathrm{mg}$ once daily was shown to be an effective and safe treatment for recurrent ovarian cancer [98]. Veenhof also noted the efficacy of hormone treatment (Table 2) [99]. Ovarian cancer cells were shown to be resistant to megestrol acetate, a kind of progestin hormone treatment. In 72 patients, megestrol acetate $800 \mathrm{mg}$ /day for one month preceded by $400 \mathrm{mg} /$ day as a maintenance dose was given, with results demonstrating that increasing the dose did not increase the all-inclusive $10 \%$ benefit of hormone therapy for chemotherapy-resistant ovarian cancer [99].

Another post-M.D. study investigated the effects of progesterone and estrogen on 2933 women with advanced epithelial ovarian cancer. For advanced serous ovarian cancers and endometrioid carcinoma, ER and PR are predictive indicators. In this study, PR expression was associated with improved disease-specific survival in endometrioid carcinoma (logrank $p<0.0001$ ) and high-grade serous carcinoma (log-rank $p=0.0006)$, and ER expression was associated with improved disease-specific survival in endometrioid carcinoma (logrank $p<0.0001$ ) [100]. John reported that 12 weeks of treatment with a combination of $2.5 \mathrm{mg}$ twice daily letrozole and $10 \mathrm{mg}$ twice daily everolimus in 20 patients led to a $47 \%$ progression-free survival with tolerable toxicity in individuals with ER-positive recurrent advanced ovarian cancer [101].

Estrone sulfate (E1S) is used to treat gynecological cancers. After 15 and 60 min incubation times, 12 postmenopausal women with non-estrogen-producing ovarian tumors were given 20 pmol of [3H] E1S in $100 \mathrm{~mL}$ of Tris-HCl. According to Dmitrijus, in postmenopausal women with non-estrogen-producing ovarian tumors, tumor tissue transformation of circulating E1S to E2 might be one of the major causes of high S-E2 levels [102]. However, the injection of a single dose of gonadotropin daily in 100 infertile clomiphene citrate-resistant women with PCOS appeared to be more successful at inducing ovulation [103]. 
Table 2. Experimental and clinical studies of hormonal therapy to treat ovarian cancer.

\begin{tabular}{|c|c|c|c|c|c|}
\hline $\begin{array}{l}\text { Name of } \\
\text { Hormone }\end{array}$ & $\begin{array}{c}\text { Formulation } \\
\text { Name and Dose }\end{array}$ & Observation time & Study Model & Results & References \\
\hline GnRHa & $\begin{array}{l}\text { Leuprolide acetate } \\
\qquad(1 \mathrm{mg})\end{array}$ & 8 weeks & 23 patients & $\begin{array}{c}\text { Showed evidence of } \\
\text { antitumor activity } \\
\text { against refractory grade } \\
1 \text { epithelial } \\
\text { adenocarcinoma of } \\
\text { the ovary }\end{array}$ & [96] \\
\hline $\begin{array}{l}\text { Aromatase } \\
\text { inhibitor }\end{array}$ & $\begin{array}{l}\text { Letrozole }(2.5 \mathrm{mg} \\
\text { daily) at the time } \\
\text { of CA125 relapse }\end{array}$ & 12 weeks & 60 patients & $\begin{array}{l}\text { Produced disease } \\
\text { stabilization and CA125 } \\
\text { responses that in turn } \\
\text { are linked to higher } \\
\text { levels of ER expression }\end{array}$ & [97] \\
\hline $\begin{array}{l}\text { Aromatase } \\
\text { inhibitor }\end{array}$ & $\begin{array}{l}\text { Letrozole at a dose } \\
\text { of } 2.5 \mathrm{mg} \text { once } \\
\text { a day }\end{array}$ & & 27 patients & $\begin{array}{l}\text { The aromatase inhibitor } \\
\text { letrozole is an agent } \\
\text { with some activity and } \\
\text { limited toxicity for } \\
\text { relapsed ovarian cancer. }\end{array}$ & [98] \\
\hline Progestin & $\begin{array}{l}\text { Megestrol acetate: } \\
800 \mathrm{mg} / \text { day for } 1 \\
\text { month followed by } \\
400 \mathrm{mg} / \text { day as } \\
\text { maintenance } \\
\text { treatment }\end{array}$ & 1 month & 72 patients & $\begin{array}{c}\text { This study does not } \\
\text { suggest that the overall } \\
10 \% \text { benefit from } \\
\text { hormonal therapy for } \\
\text { chemotherapy refractory } \\
\text { ovarian cancer will } \\
\text { improve by increasing } \\
\text { the dose }\end{array}$ & [99] \\
\hline $\begin{array}{l}\text { Estrogen, } \\
\text { progesterone }\end{array}$ & - & & 2933 women & $\begin{array}{l}\text { PR expression and ER } \\
\text { expression were } \\
\text { associated with } \\
\text { improved } \\
\text { disease-specific survival }\end{array}$ & [100] \\
\hline $\begin{array}{l}\text { Aromatase } \\
\text { inhibitor }\end{array}$ & $\begin{array}{l}\text { Oral everolimus } \\
10 \mathrm{mg} \text { daily and } \\
\text { letrozole } \\
2.5 \mathrm{mg} \text { daily }\end{array}$ & $\begin{array}{l}12 \text { weeks of } \\
\text { therapy with the } \\
\text { combination of } \\
\text { everolimus } \\
\text { and letrozole }\end{array}$ & 20 patients & $\begin{array}{l}\text { Associated with a } \\
\text { promising }(47 \%) \\
\text { progression-free } \\
\text { survival rate in patients } \\
\text { with ER-positive } \\
\text { relapsed high-grade } \\
\text { ovarian cancer }\end{array}$ & [101] \\
\hline Gonadotropin & $\begin{array}{c}\text { Injection } \\
\text { of single dose } \\
\text { gonadotropin daily }\end{array}$ & 2003-2008 & $\begin{array}{l}100 \text { infertile } \\
\text { clomiphene-citrate } \\
\text { resistance women } \\
\text { with POCS }\end{array}$ & $\begin{array}{l}\text { Pregnancy and abortion } \\
\text { rate in infertile women } \\
\text { of PCOS receiving } \\
\text { gonadotropin as a } \\
\text { treatment for induction } \\
\text { of ovulation seems to be } \\
\text { more effective }\end{array}$ & [103] \\
\hline E1S & $\begin{array}{c}20 \text { pmol of }[3 \mathrm{H}] \\
\text { E1S in } 100 \mathrm{~mL} \text { of } \\
\text { Tris- } \mathrm{HCl}\end{array}$ & $\begin{array}{l}\text { (15 and } 60 \mathrm{~min} \text { ) } \\
\text { incubation time }\end{array}$ & $\begin{array}{l}12 \text { postmenopausal } \\
\text { women }\end{array}$ & $\begin{array}{c}\text { Conversion of } \\
\text { circulating } E_{1} S \text { to } E_{2} \text { by } \\
\text { the tumor tissue could } \\
\text { be one important reason } \\
\text { for elevated } S-E_{2} \text { levels } \\
\text { in postmenopausal } \\
\text { women with } \\
\text { non-estrogen-producing } \\
\text { ovarian tumors }\end{array}$ & [104] \\
\hline
\end{tabular}




\subsection{Hormonal Therapy for Uterine Cancer}

Endometrial cancer is hormone-dependent and is usually preceded by endometrial hyperplasia. A variety of histologic subgroups have been identified, each with its own natural history. Although no link has been found between molecular profile, histology, and hormone response, the underlying biology has been discussed [102]. Hormonal treatments for endometrial cancer include tamoxifen, GnRHa, aromatase inhibitors (AIs), progestins, and luteinizing hormone-releasing hormone agonists (LHRH agonists) (Figure 2) [105].

\subsubsection{Progestins}

Progesterone is an endometrial hormone that inhibits estrogen-induced growth. Though endometrial neoplasias can decline in response to progestin therapy, this is not always the case [56]. Progesterone or medications similar to it (progestins) are the most common hormone treatments for endometrial cancer. The two most commonly used progestins are megestrol acetate, which is taken as a tablet or a fluid, and medroxyprogesterone acetate, which is administered as an injection or a tablet. The proliferation of endometrial cancer cells is slowed by these medications. They have been found to be beneficial in the treatment of women who have endometrial cancer and desire to conceive in the future [106]. Stromal proliferation and the endometrial gland are both reduced by progestins. They can reduce cyclin-dependent kinase (CDK) expression and increase the expression of an endogenous CDK inhibitor, p27, preventing CDKs from binding to cyclins and blocking cell cycle progression, resulting in cell growth suppression. Medroxyprogesterone acetate (MPA) and megestrol acetate (MA) are two of the most regularly utilized progestins (Figure 2) [107,108].

The use of estrogens for a long duration without progestins, or with the periodic addition of progestins, increases the risk of endometrial cancer. To reduce the risk of endometrial cancer associated with estrogen replacement treatment, progestins may need to be given on a regular basis. Medications containing only estrogens were linked to a significant increase in endometrial cancer risk, which increased with time and dosage [109]. In order to successfully prevent the heightened risk of endometrial cancer, the progestin in successive estrogen-progestin replacement treatment must be administered for at least 10 days. The use of a continuous estrogen-progestin combination is also successful. Neither treatment lowers a woman's risk of endometrial cancer. The stark difference in the impacts of progestin usage for 10 or more days (viably 10 days) compared to less than 10 days (viably 7 days) in sequential estrogen-progestin replacement therapy implies that the degree of endometrial sloughing may be a key factor in assessing endometrial cancer risk [110].

\subsubsection{GnRHa}

GnRHa is a synthetic GnRH analog with increased half-life, stability, and affinity for the GnRH receptor. GnRHa competes with GnRH for the binding site of the GnRH receptor, inhibiting $\mathrm{G}$ release from the hypophysis and lowering estrogen levels. When GnRH or GnRHa levels are raised, LH and follicle-stimulating hormone (FSH) levels rise quickly [111]. It was shown that the GnRH receptor is expressed in approximately $80 \%$ of ESS, implying that GnRHa may be activated by inhibiting these GnRH-R [112]. Furthermore, studies in vivo and in vitro $[113,114]$ showed medication with standard doses of GnRH agonists, which restrict ovarian estrogen production and pituitary gonadotropin release, have become a part of early stage EC or pre-cancer (atypical endometrial hyperplasia) fertility preservation treatment. In severe or recurring EC, typical doses of GnRH agonists demonstrated only minimal activity. Clinical trials using higher doses or stronger analogs, such as GnRH-II antagonists, have yet to be conducted. In a phase II study, the GnRH analog zoptarelin doxorubicin, which is cytotoxic, showed promising effects in patients diagnosed with recurrent or advanced EC that expressed GnRH-R. The cytotoxic GnRH doxorubicin compound was no better than free doxorubicin in a phase III study in patients who had EC with undetermined GnRH-R expression. Future clinical studies focusing on the GnRH system in EC with better planning and design might be beneficial [115]. 


\subsubsection{Aromatase Inhibitors}

Aromatase inhibitors, which have been shown to reduce the risk of breast cancer and levels of endogenous estrogen, may also minimize the risk of developing endometrial cancer [116]. In almost $60 \%$ of uLMS and $80 \%$ of LGESS, aromatase was expressed in the tumor. Aromatase inhibitors also inhibit both the production of estrogen inside tumor cells and the amount of estrogen in the blood by decreasing the action of aromatase in peripheral tissues [117,118]. For the clinician, metastatic/recurrent endometrial adenocarcinoma that is resistant to local or regional treatment or/and chemotherapy is a disheartening clinical entity. A 58-year-old woman with persistent endometrial cancer that was resistant to treatment with chemotherapy was effectively treated with anastrozole, an aromatase inhibitor [119].

\subsubsection{SERMs}

SERMs are a class of estrogen receptor modulators that include the nonsteroidal drugs toremifene and tamoxifen, as well as the steroidal fulvestrant. Tamoxifen and toremifene have been shown to reproduce the action of estrogen in the uterus, stimulating the growth of endometrial cancer $[120,121]$. Hormonal treatment has been shown to be beneficial for metastatic, recurrent, or unresectable low-grade endometrial stromal sarcoma (LGESS) and hormone receptor-positive $(\mathrm{ER}+/ \mathrm{PR}+)$ uterine leiomyosarcoma (uLMS) with good tolerance and cooperation. Hormonal medication can be further utilized to preserve fertility in people with early stage cancer [55]. Low-grade endometrial stromal sarcoma (EES) is an uncommon tumor with high recurrence but favorable prognosis. Case studies have documented how these recurrences respond to hormone therapy [122].

Anastrozole ( $1 \mathrm{mg} /$ day) combined with letrozole $(2.5 \mathrm{mg} /$ day) and exemestane (25 mg/day), both of which are aromatase inhibitors, can be used to treat uterine cancer. Patients who had uterine sarcoma, including four patients with ESS and three patients with LMS, were treated for 29.2 months with this medication, demonstrating that aromatase inhibitors are helpful in the treatments of ESS [117]. Ramirez treated 81 individuals with either megestrol acetate (28 patients; 35\%), medroxyprogesterone acetate (36 patients; 44\%) or progestins for 24 weeks. Most patients with well-distinguished endometrial cancer are treated with progestins in a cautious manner. Carcinoma expansion outside of the uterus is uncommon when response to progestins is not obtained or when the illness recurs [123].

A combination of endogenous or exogenous progestins and estrogen, as well as 160 mg megestrol acetate, is often a beneficial hormonal treatment for uterine cancer. Chu and Mor reported that ERT may be harmful in patients with low-grade ESS, based on a study of 22 patients, in which hormonal treatment was given for an average of 100 months (range, $2-258$ ). Reduction of ER $\beta$ might be a sign of cancer. Adjuvant progestin medication and the treatment of recurring ESS should indeed be routinely evaluated [124]. In another D. Pink trial, tamoxifen, ERT, progestin, and aromatase inhibitors were administered together for durations of 4-164 months in uterine cancer patients. Individuals with a prior record of lowgrade ESS ought not to be medicated with tamoxifen or estrogens, according to the results of a sarcoma database that was checked for all occurrences of metastatic ESS detected since 1999, including approximately 800 patients. Letrozole and MPA are extremely efficient and, in most cases, result in long-term illness stabilization [120]. Furthermore, 13 women were given MA and letrozole for 4-252 months (median 48 months). For patients with significant recurrent or residual low-grade ESS, hormonal therapy with aromatase inhibitors and progestin had good reliability and should be regarded as the preferred treatment if recurring illness cannot be effectively resected [122].

Mizuno reported that medroxyprogesterone acetate (MPA), a treatment that uses progesterone, was used on 13 successive patients with low-grade ESS for an average of 64 months (ranging from 28-92 months). During the 117-month follow-up timeframe, MPA treatment for recurrent or residual illness resulted in good control of disease over a period of 5 years. These findings suggest that MPA treatment could be explored as a possible treatment for persistent or recurrent low-grade ESS [125]. In another study, 40 patients 
with advanced uLMS were treated with aromatase inhibitors such as letrozole (in 74\% of patients), exemestane (in $6 \%$ of patients), and anastrozole (in $21 \%$ of patients), with only $9 \%$ obtaining an objective response. Patients who had ER+ and/or PR+tumors had a longer progression-free survival than those with ER - and PR - tumors [126].

Aromatase inhibitors and progestin were used in the case of a 48-year-old woman identified with stage I ESS. The patient was given three rounds of bleomycin, etoposide, and cisplatin (BEP), megestrol acetate, and anastrozole, and was monitored for two years. ESS can be healed with aromatase inhibitors and progestin, according to the findings, since ESSs with a sex-cord stromal component are hormonally functional [127]. Murphy reported a patient with an enlarged uterus, dysmenorrhea, and menorrhagia who was medicated with adriamycin, GnRH agonist, ifosfamide, leuprolide acetate, and cisplatin and monitored for 15 months following diagnosis. The symptoms of leiomyosarcomas, such as rapidly increasing uterine masses, pelvic discomfort, and uterovaginal hemorrhage, are disguised by GnRH medication. However, in this case, the latency in surgical treatment during GnRH administration resulted in a negative outcome (Table 3) [128].

Table 3. Experimental and clinical studies of hormonal therapy to treat uterine cancer.

\begin{tabular}{|c|c|c|c|c|c|}
\hline $\begin{array}{l}\text { Name of } \\
\text { Hormone }\end{array}$ & $\begin{array}{c}\text { Formulation } \\
\text { Name and Dose }\end{array}$ & Observation Time & Study Model & Results & References \\
\hline $\begin{array}{l}\text { Aromatase } \\
\text { Inhibitor }\end{array}$ & $\begin{array}{c}\text { Anastrozole } \\
\text { (1 mg/day), } \\
\text { exemestane } \\
\text { (25 mg/day)-1 } \\
\text { patient, letrozole } \\
\text { (2.5 mg/day) }\end{array}$ & 29.2 months & $\begin{array}{c}\text { Patients with } \\
\text { uterine sarcoma } \\
\text { (4 patients with } \\
\text { ESS, endometrial } \\
\text { stromal sarcoma, } \\
\text { and } 3 \text { patients } \\
\text { with LMS) }\end{array}$ & $\begin{array}{l}\text { Effective in the treatment of } \\
\text { endometrial stromal sarcomas }\end{array}$ & [117] \\
\hline Progesterone & $\begin{array}{c}\text { Medroxy } \\
\text { progesterone } \\
\text { acetate ( } 36 \text { patients; } \\
44 \% \text { ) or megestrol } \\
\text { acetate( } 28 \text { patients; } \\
35 \% \text { ), progestins }\end{array}$ & 24weeks & 81 patients & $\begin{array}{c}\text { When disease recurs, } \\
\text { carcinoma extending beyond } \\
\text { the uterus is rare in patients } \\
\text { reported with } \\
\text { well-differentiated } \\
\text { endometrial adenocarcinoma } \\
\text { who undergo treatment with a } \\
\text { progestational agent }\end{array}$ & [123] \\
\hline $\begin{array}{l}\text { Estrogen, } \\
\text { progestin, } \\
\text { aromatase } \\
\text { inhibitors }\end{array}$ & $\begin{array}{l}\text { ERT, tamoxifen, } \\
\text { progestins, } \\
\text { aromatase } \\
\text { inhibitors }\end{array}$ & 4 to 164 months & 800 patients & $\begin{array}{l}\text { MPA and letrozole, in } \\
\text { particular, are highly effective } \\
\text { and lead to sustained disease } \\
\text { control in most cases }\end{array}$ & {$[120]$} \\
\hline $\begin{array}{c}\text { Progestin, } \\
\text { Aromatase } \\
\text { inhibitors }\end{array}$ & $\begin{array}{c}\text { Megestrol acetate } \\
\text { (MA), } \\
\text { Aromatase } \\
\text { inhibitor } \\
\text { (letrozole) }\end{array}$ & $\begin{array}{l}4+\text { to } 252+\text { months } \\
\text { (median } 48+ \\
\text { months). }\end{array}$ & 11 patients & $\begin{array}{l}\text { Hormonal treatment for } \\
\text { measurable residual or } \\
\text { recurrent low-grade ESS has a } \\
\text { high response rate and should } \\
\text { be considered as the treatment } \\
\text { of choice for patients in which } \\
\text { recurrent disease cannot } \\
\text { easily be eliminated }\end{array}$ & {$[122]$} \\
\hline $\begin{array}{l}\text { Exogenous or } \\
\text { endogenous } \\
\text { estrogen and } \\
\text { progestins }\end{array}$ & $\begin{array}{l}\text { Megestrol acetate } \\
160 \mathrm{mg} \text {, progestins }\end{array}$ & $\begin{array}{l}100 \text { months } \\
\text { (range, 2-258) }\end{array}$ & 22 patients & $\begin{array}{l}\text { ERT was detrimental in } \\
\text { patients with low-grade } \\
\text { endometrial stromal sarcoma, } \\
\text { but progestin therapy should } \\
\text { be routinely considered for } \\
\text { adjuvant therapy and for the } \\
\text { treatment of recurrent } \\
\text { endometrial stromal sarcomas }\end{array}$ & {$[124]$} \\
\hline
\end{tabular}


Table 3. Cont.

\begin{tabular}{|c|c|c|c|c|c|}
\hline $\begin{array}{l}\text { Name of } \\
\text { Hormone }\end{array}$ & $\begin{array}{l}\text { Formulation } \\
\text { Name and Dose }\end{array}$ & Observation Time & Study Model & Results & References \\
\hline Progesterone & $\begin{array}{c}\text { Medroxy } \\
\text { progesterone } \\
\text { acetate (MPA) }\end{array}$ & $\begin{array}{l}\text { Dosing period } \\
64 \text { months (range } \\
28-92 \text { months) but } \\
\text { follow-up period } \\
\text { was } 117 \text { months }\end{array}$ & 13 patients & $\begin{array}{l}\text { MPA therapy might be } \\
\text { considered as a therapeutic } \\
\text { option for residual or } \\
\text { recurrent low-grade ESS and } \\
\text { perhaps chosen as a } \\
\text { first-line therapy }\end{array}$ & [125] \\
\hline Aromatase & $\begin{array}{c}\text { Aromatase } \\
\text { inhibitors used } \\
\text { were letrozole (in } \\
74 \% \text { of patients), } \\
\text { anastrozole }(21 \%), \\
\text { and exemestane }(6 \%)\end{array}$ & $\begin{array}{l}\text { Between } 1998 \text { and } \\
2008\end{array}$ & 40 patients & $\begin{array}{c}\text { Aromatase inhibitors } \\
\text { achieved objective response in } \\
\text { only } 9 \% \text {. Progression free } \\
\text { survival was longer among } \\
\text { patients with ER and/or PR } \\
\text { positive tumors than among } \\
\text { patients with ER and PR } \\
\text { negative tumors }\end{array}$ & [126] \\
\hline GnRH agonist & $\begin{array}{l}\text { GnRH agonist, } \\
\text { leuprolide acetate, } \\
\text { adriamycin, } \\
\text { cisplatin, } \\
\text { ifosfamide etc. }\end{array}$ & 15 months & $\begin{array}{l}\text { A patient with } \\
\text { menorrhagia, } \\
\text { dysmenorrhea, } \\
\text { and an } \\
\text { enlarged uterus }\end{array}$ & $\begin{array}{l}\text { GnRH therapy mask the } \\
\text { symptoms of } \\
\text { leiomyosarcomas, e.g., rapidly } \\
\text { enlarging uterine mass, pelvic } \\
\text { pain, uterovaginal bleeding }\end{array}$ & [133] \\
\hline $\begin{array}{l}\text { Progestin and } \\
\text { aromatase }\end{array}$ & $\begin{array}{l}\text { Three cycles of } \\
\text { BEP (bleomycin, } \\
\text { etoposide, } \\
\text { cisplatin), } \\
\text { anastrozole and } \\
\text { megestrol acetate }\end{array}$ & 2 years & $\begin{array}{l}\text { 48-year-old } \\
\text { woman was } \\
\text { diagnosed with } \\
\text { stage I } \\
\text { endometrial } \\
\text { stroma sarcoma }\end{array}$ & $\begin{array}{l}\text { Endometrial stromal sarcoma } \\
\text { with sex-cord stromal } \\
\text { component may be } \\
\text { hormonally functional and } \\
\text { can be cured by treating with } \\
\text { progestin and } \\
\text { aromatase inhibitor }\end{array}$ & [127] \\
\hline $\begin{array}{c}\text { Estrogen, } \\
\text { progesterone }\end{array}$ & $\begin{array}{l}\text { Megestrol acetate } \\
\text { and tamoxifen }\end{array}$ & 6 months & $\begin{array}{l}\text { A 22-year-old } \\
\text { nullipara }\end{array}$ & $\begin{array}{l}1 \text { year after the last curettage, } \\
\text { there is no evidence of disease }\end{array}$ & [130] \\
\hline $\begin{array}{l}\text { Estrogen, } \\
\text { progesterone }\end{array}$ & $\begin{array}{l}\text { Combinations of } \\
\text { megestrol acetate } \\
\text { (160 mg/day), } \\
\text { tamoxifen } \\
\text { (30 mg/day), } \\
\text { and GnRHa }\end{array}$ & 6 months & $\begin{array}{l}9 \text { patients with } \\
\text { clinically } \\
\text { diagnosed } \\
\text { endometrial } \\
\text { adenocarcinoma } \\
\text { stage IA, grade } 1\end{array}$ & $\begin{array}{l}\text { Of the } 9 \text { patients, } 8(88.9 \%) \\
\text { achieved complete remission } \\
\text { after hormone therapy. All } \\
\text { nine patients have been alive } \\
\text { without evidence of disease }\end{array}$ & [129] \\
\hline $\begin{array}{l}\text { Estrogen, } \\
\text { progesterone, } \\
(\mathrm{GnRHa})\end{array}$ & $\begin{array}{c}\text { Megestrol } \\
\text { (1-month), } \\
\text { tamoxifen } \\
\text { (20 mg/day) and } \\
\text { depot leuprolide } \\
\text { acetate } \\
\text { subcutaneous } \\
\text { injection } \\
\text { (3.75 mg/month) }\end{array}$ & 6-months & $\begin{array}{c}\text { A 36-year-old } \\
\text { nulliparous } \\
\text { woman }\end{array}$ & $\begin{array}{l}\text { This case report signals a } \\
\text { warning that negative clinical } \\
\text { investigations are not } \\
\text { reassuring for a relapsing } \\
\text { endometrial adenocarcinoma } \\
\text { failing conservative } \\
\text { hormonal treatment }\end{array}$ & [131] \\
\hline $\begin{array}{l}\text { Estrogen, } \\
\text { progestin }\end{array}$ & $\begin{array}{l}500 \text { mg of oral } \\
\text { medroxyproges- } \\
\text { terone for } \\
6 \text { months, } \\
\text { twice weekly }\end{array}$ & $\begin{array}{l}9 \text { months (range, } \\
\text { 3-18 months) }\end{array}$ & 2 women & $\begin{array}{l}\text { The quarterly interval for } \\
\text { D\&Cs was satisfactory with } \\
\text { medroxyprogesterone } \\
\text { treatment, and the patients' } \\
\text { desire not to undergo } \\
\text { hysterectomy was met }\end{array}$ & [132] \\
\hline
\end{tabular}

The efficacy of tamoxifen and megestrol acetate, hormonal treatment with progestins and estrogen, and GnRHa in uterine cancer is well established (Figure 2). A combination of GnRHa, tamoxifen (30 mg/day), and megestrol acetate (160 mg/day) was given to 
9 patients with confirmed stage IA, grade 1 endometrial adenocarcinoma. After treatment for 6 months, $8(88.9 \%)$ of the 9 patients achieved full recovery. All nine of the patients have been disease-free for 25-113 (median 69) months since their first diagnosis [129]. In a study by Fu, a 22-year-old nullipara was treated with tamoxifen and megestrol acetate for 6 months and 1 year respectively after curettage, and there was no sign of illness [130]. Shih and Jung reported that megestrol (1 month), tamoxifen ( $20 \mathrm{mg} /$ day), and depot leuprolide acetate subcutaneous injection $(3.75 \mathrm{mg} / \mathrm{month})$ were used to treat a 36 -yearold nulliparous woman with stage IA, grade 1 endometrial cancer. They concluded that adverse clinical examinations are not encouraging for a recurrent low-grade, early-stage endometrial adenocarcinoma without conventional hormonal therapy [131]. In two women of reproductive age, $500 \mathrm{mg}$ of oral medroxyprogesterone was administered for 6 months and twice weekly for 9 months. With medroxyprogesterone medication, the quarterly timeframe for D\&Cs was acceptable, and the patients' wishes to avoid hysterectomy were fulfilled. As a result, the progestin and estrogen-based hormone therapy proved effective in the treatment of uterine cancer [132]. Endometrial cancer prevalence was reduced in women on an aromatase inhibitor in comparison to those taking tamoxifen in a peer group-based, coordinated health care plan system. Aromatase inhibitors may also help to reduce the risk of tamoxifen-related endometrial cancer. Although the aromatase inhibitor group had somewhat fewer endometrial malignancies than the no treatment group, further research is required to evaluate this possible relationship [116].

\subsection{Hormonal Therapy for Vaginal Cancer}

Vaginal carcinoma is a rare gynecologic malignancy. Surgery can be used to treat vaginal carcinoma in situ and extremely early stage invasive cancer of the vagina. Radiation therapy is the usual treatment for women with vaginal cancer. To maintain the structure and functionality of the vagina, radiotherapy is used as a treatment of last resort for early phase vaginal cancer. Radiation therapy is used to prevent exenterative surgery, maintain function and anatomy, and address identified or suspected lymph node metastases in later stages of vaginal cancer. Estrogen (estrone sulfate) in the form of vaginal promestriene (10 $\mathrm{mg}$ soft vaginal suppository) was given to 17 postmenopausal women daily for one to six months to treat vaginal cancer. The amount of circulating E1S in extremely symptomatic gynecological cancer patients was not influenced by vaginal promestriene treatment, although there was a broad range of individual values before and after treatment [66].

To investigate ElS as a hormonal treatment, the AC-258 cell line and the squamous vaginal carcinoma cell line EC-82 were treated with ElS and DS $(2.25 \mu \mathrm{Ci}, 15 \mu \mathrm{M})$ for at least two hours using cell densities of up to $3.2 \times 10^{6}$ cells $/ \mathrm{mL}$. In situ estrogen synthesis from steroid sulfate antecedents in the organs and tissues of and around the reproductive tract may influence the growth of ovarian and vaginal tumors [134]. Meanwhile, in a 52-week double-blind, randomized, placebo-controlled trial, 205 postmenopausal women were given an ultra-low-dose $10 \mu \mathrm{g}$ 17-estradiol vaginal tablet, which did not increase the incidence of endometrial carcinoma or hyperplasia [135]. A study of 423 women who were given local estrogen therapy in the form of either estradiol cream ( $0.1 \mathrm{mg}$ estradiol/g USP) or estradiol vaginal tablets $(10 \mathrm{~g})$ reported that vaginal tablets have higher compliance than vaginal cream, with the majority of respondents preferring vaginal tablets [136]. The impact of estrogen on vaginal cancer was also reported in a study in which the estrogen receptor modulator ospemifene was given for one month to 32 postmenopausal women receiving surgical intervention, with the results demonstrating that ospemifene improved the signs of atrophy and cancer by enhancing ER $\alpha$ expression and maturation of the vaginal mucosa [137]. Bachmann reported that 30 or $60 \mathrm{mg} /$ day ospemifene for 12 weeks was efficacious for the treatment of vaginal dryness and dyspareunia (that can progress to vulvovaginal malignancy and atrophy if left untreated) but also better received in 826 postmenopausal women (Table 4) [138]. 
Table 4. Experimental and clinical studies of hormonal therapy to treat vaginal cancer.

\begin{tabular}{|c|c|c|c|c|c|}
\hline $\begin{array}{l}\text { Name of } \\
\text { Hormone }\end{array}$ & $\begin{array}{c}\text { Formulation } \\
\text { Name and Dose }\end{array}$ & Observation Time & Study Model & Results & References \\
\hline $\begin{array}{c}\text { Estrogen (estrone } \\
\text { sulfate) }\end{array}$ & $\begin{array}{c}\text { Vaginal } \\
\text { promestriene } \\
10 \text { mg soft vaginal } \\
\text { suppository daily } \\
\text { for one month }\end{array}$ & $1-6$ months & $\begin{array}{l}17 \text { patients (after } \\
\text { menopause) }\end{array}$ & $\begin{array}{l}\text { The level of circulating E1S } \\
\text { was not significantly } \\
\text { affected by vaginal } \\
\text { promestriene treatment, but } \\
\text { a wide range of levels was } \\
\text { noted pre- and } \\
\text { post-treatment in } \\
\text { individual patients }\end{array}$ & {$[66]$} \\
\hline E1S & $\begin{array}{c}\text { ElS and DS } \\
(2.25 \mu \mathrm{Ci}, 15 \mu \mathrm{M})\end{array}$ & $\begin{array}{l}\text { Incubation time for } \\
\text { at least } 2 \mathrm{~h} \text { and } \\
\text { with cell number } \\
\text { up to } \\
3.2 \times 10^{6} \text { cells } / \mathrm{mL}\end{array}$ & $\begin{array}{l}\text { AC-258 cell line, } \\
\text { squamous } \\
\text { vaginal carcinoma } \\
\text { cells (line EC-82) }\end{array}$ & $\begin{array}{l}\text { Played a role in the } \\
\text { development of tumors of } \\
\text { the ovary and vagina }\end{array}$ & {$[134]$} \\
\hline Estradiol & $\begin{array}{l}\text { Ultra-low-dose } \\
10 \text {-microgram } \\
17 \beta \text {-estradiol } \\
\text { vaginal tablets }\end{array}$ & 52 weeks & $\begin{array}{l}(n=205) \text { in a } \\
\text { randomized, } \\
\text { double-blind, } \\
\text { placebo- } \\
\text { controlled trial }\end{array}$ & $\begin{array}{c}\text { There was no increased risk } \\
\text { of endometrial hyperplasia } \\
\text { and carcinoma in } \\
\text { postmenopausal women }\end{array}$ & {$[135]$} \\
\hline Estrogen & $\begin{array}{l}\text { Local estrogen } \\
\text { therapy (LET) in } \\
\text { form of estradiol } \\
\text { vaginal tablets, } \\
10 \mu g \text {, estradiol } \\
\text { cream, } 0.1 \mathrm{mg} \\
\text { estradiol/g USP }\end{array}$ & $\begin{array}{l}\text { 5-week period, } \\
\text { from } 6 \text { March } 2012 \\
\text { through } \\
9 \text { April } 2012\end{array}$ & 423 women & $\begin{array}{l}\text { There was greater } \\
\text { compliance with vaginal } \\
\text { tablets than with vaginal } \\
\text { cream; respondents } \\
\text { preferred their current } \\
\text { treatment with the } \\
\text { vaginal tablet }\end{array}$ & {$[136]$} \\
\hline Estrogen & $\begin{array}{l}\text { ER modulator } \\
\text { (ospemifene) }\end{array}$ & 1 month & $\begin{array}{l}32 \text { postmenopausal } \\
\text { women }\end{array}$ & $\begin{array}{l}\text { Increased maturation, and } \\
\text { ER } \alpha \text { expression of the } \\
\text { vaginal mucosa. These } \\
\text { changes partially explained } \\
\text { the improvement of } \\
\text { symptoms of vaginal } \\
\text { atrophy and cancer }\end{array}$ & {$[137]$} \\
\hline ER modulator & $\begin{array}{c}\text { Ospemifene } 30 \text { or } \\
60 \mathrm{mg} / \text { day }\end{array}$ & 12 weeks & $\begin{array}{l}826 \\
\text { postmenopausal } \\
\text { women were } \\
\text { randomized }\end{array}$ & $\begin{array}{l}\text { Effective and well tolerated } \\
\text { for the treatment of the } \\
\text { symptoms of vaginal } \\
\text { dryness and dyspareunia } \\
\text { associated with } \\
\text { vulvovaginal atrophy over }\end{array}$ & {$[138]$} \\
\hline
\end{tabular}

\subsection{Hormonal Therapy for Vulvar Cancer}

Jacob reported that HRT with progesterone and estrogen in a population of 7189 women was not harmful. The majority of vulvar malignancies in this cohort were estrogenindependent squamous cell carcinomas [139]. The estrogen receptor modulator ospemifene was found to be helpful for the prevention of vaginal and vulvar cancer and atrophy in women with dyspareunia in a study of 605 postmenopausal women using oral ospemifene $60 \mathrm{mg} /$ day for 12 weeks [140].

The estrogen receptor modulator bazedoxifene (BZA) was given to 664 postmenopausal women for 12 weeks at doses of $20 \mathrm{mg} / \mathrm{CE}, 0.625 \mathrm{mg}, 0.45 \mathrm{mg}$, and $20 \mathrm{mg}$. BZA/CE was efficacious in preventing mild-to-advanced VVA and vaginal symptoms. These findings suggest the use of a BZA/CE-containing tissue-selective estrogen complex as a potential menopause treatment for postmenopausal women [141]. Conjugated estrogens $0.625 \mathrm{mg}$ and $0.45 \mathrm{mg}$ BZA $20 \mathrm{mg}$ were administered to 2 groups of 1583 postmenopausal women and provided endometrial protection without increasing breast pain/density, vaginal bleed- 
ing, or ovarian cysts after 2 years of observation [75]. Additionally, in 652 symptomatic postmenopausal women, therapy with BZA/CE for a duration of 12 weeks dramatically enhanced quality-of-life parameters and attenuated cancer [142]. Following a 12-week study of 25 women with endometrial biopsies, Mirkin speculated that $4 \mu \mathrm{g}$ and $10 \mu \mathrm{g}$ vaginal estradiol (E2) does not cause endometrial hyperplasia resulting in moderate to severe dyspareunia, which is also considered to be a symptom of vaginal and vulvar cancer and atrophy (Table 5) [143].

Table 5. Experimental and clinical studies of hormonal therapy to treat vulvar cancer.

\begin{tabular}{|c|c|c|c|c|c|}
\hline $\begin{array}{l}\text { Name of } \\
\text { Hormone }\end{array}$ & $\begin{array}{c}\text { Formulation } \\
\text { Name and Dose }\end{array}$ & $\begin{array}{l}\text { Observation } \\
\text { Time }\end{array}$ & Study Model & Results & References \\
\hline $\begin{array}{c}\text { Estrogen, } \\
\text { progesterone }\end{array}$ & $\begin{array}{l}\text { Hormone } \\
\text { replacement } \\
\text { therapy }\end{array}$ & 12 months & 7189 women & $\begin{array}{l}\text { Significantly decreased the } \\
\text { proportion of women } \\
\text { receiving at least one HRT } \\
\text { prescription. The majority } \\
\text { of vulvar cancers are not } \\
\text { estrogen-dependent, and } \\
\text { the prescription of HRT is } \\
\text { not contraindicated after the } \\
\text { diagnosis of this type } \\
\text { of cancer }\end{array}$ & [139] \\
\hline ER modulator & $\begin{array}{l}\text { Oral ospemifene } \\
60 \mathrm{mg} / \text { day }\end{array}$ & 12 weeks & 605 women & $\begin{array}{l}\text { Effective for the treatment of } \\
\text { vulvar and vaginal atrophy } \\
\text { and cancer in } \\
\text { postmenopausal women } \\
\text { with dyspareunia }\end{array}$ & [140] \\
\hline ER modulator & $\begin{array}{l}\text { BZA } 20 \mathrm{mg} / \mathrm{CE} \\
0.625 \mathrm{mg} \text { and } \\
0.45 \mathrm{mg}, \mathrm{BZA} \\
20 \mathrm{mg}\end{array}$ & 12 weeks & $\begin{array}{c}\text { Healthy } \\
\text { postmenopausal women } \\
(n=664 ; \text { aged } 40-65 \mathrm{y})\end{array}$ & $\begin{array}{l}\text { Effective in treating } \\
\text { moderate to severe VVA } \\
\text { and vaginal symptoms. }\end{array}$ & [141] \\
\hline $\begin{array}{l}\text { Estrogen and ER } \\
\text { modulator }\end{array}$ & $\begin{array}{c}\text { Conjugated } \\
\text { estrogens } 0.625 \mathrm{mg} \\
\text { and } 0.45 \mathrm{mg} / \mathrm{BZA} \\
20 \mathrm{mg}\end{array}$ & 2 years & $\begin{array}{l}1583 \text { and } 1583 \\
\text { postmenopausal women } \\
\text { respectively }\end{array}$ & $\begin{array}{l}\text { Conjugated estrogens/BZA } \\
\text { provides endometrial } \\
\text { protection without } \\
\text { increasing breast } \\
\text { pain/density, vaginal } \\
\text { bleeding, or ovarian cysts }\end{array}$ & [75] \\
\hline $\begin{array}{l}\text { Estrogen and ER } \\
\text { modulator }\end{array}$ & $\begin{array}{l}\text { BZA } 20 \mathrm{mg} / \mathrm{CE} \\
0.45 \text { or } 0.625 \mathrm{mg} \text {, } \\
\text { BZA } 20 \mathrm{mg} .\end{array}$ & 12 weeks & $\begin{array}{c}\text { Postmenopausal, } \\
\text { non-hysterectomized } \\
\text { women }(n=652) \text { with } \\
\text { symptoms of moderate } \\
\text { to severe vulvar/vaginal } \\
\text { atrophy }\end{array}$ & $\begin{array}{l}\text { Shown to significantly } \\
\text { improve sexual function } \\
\text { and quality-of-life measures } \\
\text { in symptomatic } \\
\text { postmenopausal women }\end{array}$ & [142] \\
\hline Estradiol & $\begin{array}{l}\text { Vaginal } 4 \mu \mathrm{g} \text { and } \\
10 \mu \mathrm{g} \text { estradiol (E2) }\end{array}$ & 12 weeks & 25 eligible women & $\begin{array}{l}\text { Because of endometrial } \\
\text { progesterone receptor } \\
\text { expression, vaginal E2 } \\
\text { would not be expected to } \\
\text { stimulate endometrial } \\
\text { hyperplasia leading to } \\
\text { moderate to severe } \\
\text { dyspareunia which is a } \\
\text { symptom of vulvar and } \\
\text { vaginal atrophy and cancer }\end{array}$ & [143] \\
\hline $\begin{array}{l}\text { Selective } \\
\text { serotonin- } \\
\text { reuptake } \\
\text { inhibitors (SSRIs) }\end{array}$ & $\begin{array}{l}7.5 \mathrm{mg} \text { oral } \\
\text { paroxetine or } \\
\text { placebo daily }\end{array}$ & 16 weeks & 80 women & $\begin{array}{l}\text { Paroxetine significantly } \\
\text { reduced hot flashes in } \\
\text { weekly frequency and } \\
\text { severity in gynecological } \\
\text { cancer survivors }\end{array}$ & [144] \\
\hline
\end{tabular}




\section{Risk Factors Associated with HRT in Gynecological Cancers}

Hormone treatment slows or prevents the growth of hormone-sensitive cancers by interacting with the actions of hormones on breast cancer cells or by limiting the body's ability to produce hormones [145]. Postmenopausal women who received "some" estrogen treatment are more likely to develop estrogen-receptor and progesterone-receptor positive breast tumors [146]. The application of antiestrogenic drugs such as nafoxidine and tamoxifen has shown to be the most effective new hormonal treatment for estrogen receptor-positive metastatic breast cancer. Both of these medications have anticancer effectiveness similar to other additive hormonal treatments, and they are better tolerated due to the lack of significant toxicity [147]. The therapeutic uses of aromatase inhibitors (AI) and GnRH agonists that limit estrogen production, tamoxifen, a selective estrogen receptor modulator (SERM), and fulvestrant, a selective ER downregulator (SERD) have resulted in significant improvements in survival outcomes for patients with ER+ breast cancer via ER-alpha (ESR1) mutation, growth factor receptor signaling, as well as PI3K/Akt/mTOR, CDK4/6, and epigenetic and immunological checkpoints as resistance mechanisms [148]. HRT may raise the risk of developing heart disease, stroke, and type 2 diabetes and inflammatory markers (such as C-reactive protein) $[149,150]$. HT may decrease stiffness of the aorta and large arteries in postmenopausal women, with potential benefit for age-related cardiovascular disorders. The reduction of arterial compliance with age appears to be altered with hormonal therapy [151].

The effects of hormone treatment against invasive ductal, lobular, and tubular carcinoma were typically larger for estrogen-progestagen therapy and lessened with rising BMI (body mass index) [152]. Tamoxifen use highly increased the incidence of secondary diabetes, although aromatase inhibitors had no effect on diabetes mellitus in individuals with initial breast cancer [153]. However, HT is a recognized risk factor for blood clots like deep vein thrombosis or pulmonary embolism [154]. Moreover, HT also raises liver disease and unusual vaginal bleeding that has not been reviewed by physicians [155]. The increased risk is related to how long the HRT is administered, and it falls after the patient stops taking it [156].

\section{Concluding Remarks and Future Directions}

HT is a promising therapeutic option for patients with recurring gynecological malignancies, whose primary goal is palliation and life extension (rather than cure). Aromatase inhibitors can be used for long periods of time with even less cumulative injury as these inhibitors are usually well tolerated. Previous studies have reported a wide range of functional properties and response rates. HT is often thought of as "less potent" in comparison to chemotherapy, yet it can be just as useful in certain types of gynecological cancer. Hormone treatment is classified as a "systemic" therapy since it affects the entire body. In addition to gynecological cancer prevention, HRT has shown potential in treating postmenopausal symptoms. HRT, such as progestin and estrogen combination therapy or estrogen monotherapy has been shown in recent trials to benefit postmenopausal women with osteoporosis as well as some concomitant disorders. HT can stop or slow the growth of cancer, and reduce the chance that it will return. To promote a better future generation and healthy life, HT for gynecological illnesses is very important. Further study and clinical trials should be undertaken to discover new benefits of HT for gynecological cancers.

Author Contributions: Conceptualization, S.M. and T.B.E.; investigation and resources, S.M., M.S.L., R.D. and A.G.; writing - original draft preparation, S.M., M.S.L., R.D. and A.G.; writing-review, updates and editing, S.M., T.E.T., F., F.I., K.D., M.Y.B., A.A., K.C. and T.B.E.; visualization and supervision, K.D., M.Y.B., A.A., K.C. and T.B.E.; formal analysis, S.M., M.Y.B., A.A., K.C. and T.B.E.; resources, T.E.T., F., F.I., K.D. and T.B.E.; project administration, T.E.T., F., F.I., K.D. and T.B.E.; funding acquisition, M.Y.B., A.A., K.C. and T.B.E. All authors have read and agreed to the published version of the manuscript. 
Funding: The authors extend their appreciation to the Deanship of Scientific Research at King Khalid University for funding this work through Research Group (Small) Project number RGP.1/330/42.

Conflicts of Interest: The authors declare no conflict of interest.

\section{References}

1. Salvo, G.; Odetto, D.; Pareja, R.; Frumovitz, M.; Ramirez, P.T. Revised 2018 International Federation of Gynecology and Obstetrics (FIGO) cervical cancer staging: A review of gaps and questions that remain. Int. J. Gynecol. Cancer 2020, 30, 873-878. [CrossRef]

2. Ratner, E.S.; Foran, K.A.; Schwartz, P.E.; Minkin, M.J. Sexuality and intimacy after gynecological cancer. Maturitas 2010, 66, 23-26. [CrossRef] [PubMed]

3. Canavan, T.P.; Doshi, N.R. Cervical cancer. Am. Fam. Physician 2000, 61, 1369-1376.

4. Ali, F.; Kuelker, R.; Wassie, B. Understanding cervical cancer in the context of developing countries. Ann. Trop. Med. Public Health 2012, 5, 3-15. [CrossRef]

5. Chung, S.H. Targeting female hormone receptors as cervical cancer therapy. Trends Endocrinol. Metab. 2015, 26, 399-401. [CrossRef] [PubMed]

6. Tummala, M.K.; McGuire, W.P. Recurrent ovarian cancer. Clin. Adv. Hematol. Oncol. 2005, 3, 723-736. [CrossRef]

7. Eisenhauer, E.L.; Salani, R.; Copeland, L.J. Epithelial Ovarian Cancer. Clin. Gynecol. Oncol. Eighth Ed. 2012, 285-328. [CrossRef]

8. Lukanova, A.; Lundin, E.; Toniolo, P.; Micheli, A.; Akhmedkhanov, A.; Rinaldi, S.; Muti, P.; Lenner, P.; Biessy, C.; Krogh, V.; et al. Circulating levels of insulin-like growth factor-I and risk of ovarian cancer. Int. J. Cancer 2002, 101, 549-554. [CrossRef]

9. Nainu, F.; Masyita, A.; Bahar, M.A.; Raihan, M.; Prova, S.R.; Mitra, S.; Emran, T.B.; Simal- Gandara, J. Pharmaceutical Prospects of Bee Products: Special Focus on Anticancer and Antimicrobial Properties. Antibiotics 2021, 10, 822. [CrossRef]

10. Momenimovahed, Z.; Ghoncheh, M.; Pakzad, R.; Hasanpour, H.; Salehiniya, H. Incidence and mortality of uterine cancer and relationship with Human Development Index in the world. Cukurova Med. J. 2017, 42, 233-240. [CrossRef]

11. Shrivastava, S.; Agrawal, G.; Mittal, M.; Mishra, P. Management of Vaginal Cancer. Rev. Recent Clin. Trials 2015, 10, 289-297. [CrossRef] [PubMed]

12. Kalliala, I.; Athanasiou, A.; Veroniki, A.A.; Salanti, G.; Efthimiou, O.; Raftis, N.; Bowden, S.; Paraskevaidi, M.; Aro, K.; Arbyn, M.; et al. Incidence and mortality from cervical cancer and other malignancies after treatment of cervical intraepithelial neoplasia: A systematic review and meta-analysis of the literature. Ann. Oncol. 2020, 31, 213-227. [CrossRef] [PubMed]

13. Pouwer, A.F.W.; Arts, H.J.; van der Velden, J.; de Hullu, J.A. Limiting the morbidity of inguinofemoral lymphadenectomy in vulvar cancer patients; a review. Expert Rev. Anticancer Ther. 2017, 17, 615-624. [CrossRef]

14. Guidozzi, F. Estrogen therapy in gynecological cancer survivors. Climacteric 2013, 16, 611-617. [CrossRef] [PubMed]

15. Chaudhry, P.; Asselin, E. Resistance to chemotherapy and hormone therapy in endometrial cancer. Endocr. Relat. Cancer 2009, 16, 363-380. [CrossRef]

16. Ibeanu, O.A. Molecular pathogenesis of cervical cancer. Cancer Biol. Ther. 2011, 11, 295-306. [CrossRef] [PubMed]

17. Kumar, U.; Khandia, R.; Singhal, S.; Puranik, N.; Tripathi, M.; Pateriya, A.K.; Khan, R.; Emran, T.B.; Dhama, K.; Munjal, A.; et al. Insight into Codon Utilization Pattern of Tumor Suppressor Gene EPB41L3 from Different Mammalian Species Indicates Dominant Role of Selection Force. Cancer 2021, 13, 2739. [CrossRef]

18. Austin, R.M.; Zhao, C. Type 1 and type 2 cervical carcinomas: Some cervical cancers are more difficult to prevent with screening Cytopathology 2012, 23, 6-12. [CrossRef]

19. Bulk, S.; Visser, O.; Rozendaal, L.; Verheijen, R.H.M.; Meijer, C.J.L.M. Cervical cancer in the Netherlands 1989-1998: Decrease of squamous cell carcinoma in older women, increase of adenocarcinoma in younger women. Int. J. Cancer 2005, 113, 1005-1009. [CrossRef]

20. Pater, A.; Bayatpour, M.; Pater, M.M. Oncogenic transformation by human papillomavirus type 16 deoxyribonucleic acid in the presence of progesterone or progestins from oral contraceptives. Am. J. Obstet. Gynecol. 1990, 162, 1099-1103. [CrossRef]

21. Chan, W.K.; Klock, G.; Bernard, H.U. Progesterone and glucocorticoid response elements occur in the long control regions of several human papillomaviruses involved in anogenital neoplasia. J. Virol. 1989, 63, 3261-3269. [CrossRef] [PubMed]

22. Schneider, A.; Hotz, M.; Gissmann, L. Increased prevalence of human papillomaviruses in the lower genital tract of pregnant women. Int. J. Cancer 1987, 40, 198-201. [CrossRef] [PubMed]

23. Monsonego, J.; Magdelenat, H.; Catalan, F.; Coscas, Y.; Zerat, L.; Sastre, X. Estrogen and progesterone receptors in cervical human papillomavirus related lesions. Int. J. Cancer 1991, 48, 533-539. [CrossRef]

24. Ibeanu, O.; Modesitt, S.C.; Ducie, J.; Von Gruenigen, V.; Agueh, M.; Fader, A.N. Hormone replacement therapy in gynecologic cancer survivors: Why not? Gynecol. Oncol. 2011, 122, 447-454. [CrossRef] [PubMed]

25. Hu, F.B.; Grodstein, F.; Hennekens, C.H.; Colditz, G.A.; Johnson, M.; Manson, J.A.E.; Rosner, B.; Stampfer, M.J. Age at natural menopause and risk of cardiovascular disease. Arch. Intern. Med. 1999, 159, 1061-1066. [CrossRef] [PubMed]

26. Jacobsen, B.K.; Heuch, I.; Kvåle, G. Age at natural menopause and all-cause mortality: A 37-year follow-up of 19,731 Norwegian women. Am. J. Epidemiol. 2003, 157, 923-929. [CrossRef] [PubMed]

27. Chung, S.H.; Franceschi, S.; Lambert, P.F. Estrogen and ER $\alpha$ : Culprits in cervical cancer? Trends Endocrinol. Metab. 2010, 21, 504-511. [CrossRef] [PubMed] 
28. Yoo, Y.A.; Son, J.; Mehta, F.F.; Demayo, F.J.; Lydon, J.P.; Chung, S.H. Progesterone signaling inhibits cervical carcinogenesis in mice. Am. J. Pathol. 2013, 183, 1679-1687. [CrossRef]

29. Kaku, T.; Ogawa, S.; Kawano, Y.; Ohishi, Y.; Kobayashi, H.; Hirakawa, T.; Nakano, H. Histological classification of ovarian cancer Med. Electron Microsc. 2003, 36, 9-17. [CrossRef]

30. Kurman, R.J.; Shih, I.M. The origin and pathogenesis of epithelial ovarian cancer: A proposed unifying theory. Am. J. Surg. Pathol. 2010, 34, 433-443. [CrossRef]

31. Boussios, S.; Zarkavelis, G.; Seraj, E.; Zerdes, I.; Tatsi, K.; Pentheroudakis, G. Non-epithelial ovarian cancer: Elucidating uncommon gynaecological malignancies. Anticancer Res. 2016, 36, 5031-5042. [CrossRef] [PubMed]

32. Shih, I.M.; Davidson, B. Pathogenesis of ovarian cancer: Clues from selected overexpressed genes. Futur. Oncol. 2009, 5, 1641-1657. [CrossRef]

33. Lengyel, E. Ovarian cancer development and metastasis. Am. J. Pathol. 2010, 177, 1053-1064. [CrossRef] [PubMed]

34. Charkhchi, P.; Cybulski, C.; Gronwald, J.; Wong, F.O.; Narod, S.A.; Akbari, M.R. Ca125 and ovarian cancer: A comprehensive review. Cancers 2020, 12, 3730. [CrossRef] [PubMed]

35. Hough, C.D.; Sherman-Baust, C.A.; Pizer, E.S.; Montz, F.J.; Im, D.D.; Rosenshein, N.B.; Cho, K.R.; Riggins, G.J.; Morin, P.J. Large-scale serial analysis of gene expression reveals genes differentially expressed in ovarian cancer. Cancer Res. 2000, 60, 6281-6287. [PubMed]

36. Kurman, R.J.; Shih, I.M. Pathogenesis of ovarian cancer: Lessons from morphology and molecular biology and their clinical implications. Int. J. Gynecol. Pathol. 2008, 27, 151-160. [CrossRef]

37. McGrail, D.J.; Kieu, Q.M.N.; Dawson, M.R. The malignancy of metastatic ovarian cancer cells is increased on soft matrices through a mechanosensitive Rho-ROCK pathway. J. Cell Sci. 2014, 127, 2621-2626. [CrossRef] [PubMed]

38. Olson, M.F.; Sahai, E. The actin cytoskeleton in cancer cell motility. Clin. Exp. Metastasis 2009, 26, 273-287. [CrossRef] [PubMed]

39. Leung, C.S.; Yeung, T.L.; Yip, K.P.; Pradeep, S.; Balasubramanian, L.; Liu, J.; Wong, K.; Mangala, L.S.; Armaiz-Pena, G.N.; Lopez-Berestein, G.; et al. Calcium-dependent FAK/CREB/TNNC1 signalling mediates the effect of stromal MFAP5 on ovarian cancer metastatic potential. Nat Commun 2014, 5, 5092. [CrossRef]

40. Yeung, T.L.; Leung, C.S.; Wong, K.K.; Samimi, G.; Thompson, M.S.; Liu, J.; Zaid, T.M.; Ghosh, S.; Birrer, M.J.; Mok, S.C. TGF- $\beta$ Modulates ovarian cancer invasion by upregulating CAF-Derived versican in the tumor microenvironment. Cancer Res. 2013, 73 , 5016-5028. [CrossRef]

41. Yeung, T.L.; Leung, C.S.; Yip, K.P.; Yeung, C.L.A.; Wong, S.T.C.; Mok, S.C. Cellular and molecular processes in ovarian cancer metastasis. A review in the theme: Cell and molecular processes in cancer metastasis. Am. J. Physiol.-Cell Physiol. 2015, 309, C444-C456. [CrossRef]

42. Chesang, J.J. Pathogenesis of ovarian cancer: Current perspectives. East Afr. Med. J. 2017, 94, 561-574.

43. Simpkins, F.; Garcia-Soto, A.; Slingerland, J. New insights on the role of hormonal therapy in ovarian cancer. Steroids 2013, 78 , 530-537. [CrossRef] [PubMed]

44. Zheng, H.; Kavanagh, J.J.; Hu, W.; Liao, Q.; Fu, S. Hormonal therapy in ovarian cancer. Int. J. Gynecol. Cancer 2007, 17, 325-338. [CrossRef] [PubMed]

45. Eva, T.A.; Barua, N.; Chowdhury, M.M.; Yeasmin, S.; Rakib, A.; Islam, M.R.; Emran, T.B.; Simal-Gandara, J. Perspectives on signaling for biological- and processed food-related advanced glycation end-products and its role in cancer progression. Crit. Rev. Food Sci. Nutr. 2020, 2020, 1-18. [CrossRef] [PubMed]

46. Liu, F.S. Molecular carcinogenesis of endometrial cancer. Taiwan. J. Obstet. Gynecol. 2007, 46, 26-32. [CrossRef]

47. Sivridis, E.; Giatromanolaki, A. The pathogenesis of endometrial carcinomas at menopause: Facts and figures. J. Clin. Pathol. 2011, 64, 553-560. [CrossRef] [PubMed]

48. Ohgami, T.; Kato, K. Pathogenesis of endometrial cancer. Curr. Approaches Endometrial Cancer 2014, 2014, 18-32. [CrossRef]

49. Kurra, V.; Krajewski, K.M.; Jagannathan, J.; Giardino, A.; Berlin, S.; Ramaiya, N. Typical and atypical metastatic sites of recurrent endometrial carcinoma. Cancer Imaging 2013, 13, 113-122. [CrossRef]

50. Thaker, P.H.; Sood, A.K. Molecular Oncology in Gynecologic Cancer. Compr. Gynecol. 2013, 2013, 623-633. [CrossRef]

51. Colombo, N.; Preti, E.; Landoni, F.; Carinelli, S.; Colombo, A.; Marini, C.; Sessa, C. Endometrial cancer: ESMO clinical practice guidelines for diagnosis, treatment and follow-up. Ann. Oncol. 2013, 24, vi33-vi38. [CrossRef] [PubMed]

52. Mani, R.S. The emerging role of speckle-type POZ protein (SPOP) in cancer development. Drug Discov. Today 2014, 19, 1498-1502. [CrossRef]

53. Boyle, P.; Levin, B. International Agency for Research on Cancer, World Cancer Report; WHO: Geneva, Switzerland, $2014 ;$ p. 630.

54. Colombo, N.; Preti, E.; Landoni, F.; Carinelli, S.; Colombo, A.; Marini, C.; Sessa, C. Endometrial cancer: ESMO clinical practice guidelines for diagnosis, treatment and follow-up. Ann. Oncol. 2011, 22, vi35-vi39. [CrossRef] [PubMed]

55. Zang, Y.; Dong, M.; Zhang, K.; Gao, C.; Guo, F.; Wang, Y.; Xue, F. Hormonal therapy in uterine sarcomas. Cancer Med. 2019, 8, 1339-1349. [CrossRef] [PubMed]

56. Kim, J.J.; Chapman-Davis, E. Role of progesterone in endometrial cancer. Semin. Reprod. Med. 2010, 28, 81-90. [CrossRef]

57. Choi, S.; Sherertz, T. Vaginal cancer. In Handbook of Evidence-Based Radiation Oncology; Springer: Berlin/Heidelberg, Germany, 2018; pp. 693-705. [CrossRef]

58. Slaughter, D.P.; Southwick, H.W.; Smejkal, W. "Field cancerization” in oral stratified squamous epithelium. Clinical implications of multicentric origin. Cancer 1953, 6, 963-968. [CrossRef] 
59. Koyamatsu, Y.; Yokoyama, M.; Nakao, Y.; Fukuda, K.; Saito, T.; Matsukuma, K.; Iwasaka, T. A comparative analysis of human papillomavirus types 16 and 18 and expression of p53 gene and Ki-67 in cervical, vaginal, and vulvar carcinomas. Gynecol. Oncol. 2003, 90, 547-551. [CrossRef]

60. Kouvaris, J.R.; Plataniotis, G.A.; Sykiotis, C.A.; Dapolla, V.J.; Vlahos, L.J. Dermal metastasis from vaginal squamous cell carcinoma. Br. J. Dermatol. 1999, 141, 579-580. [CrossRef]

61. Forsberg, J.G. Estrogen, vaginal cancer, and vaginal development. Am. J. Obstet. Gynecol. 1972, 113, 83-87. [CrossRef]

62. Atypical vaginal adenosis and cervical ectropion. Association with clear cell adenocarcinoma in diethylstilbestrol-exposed offspring. Cancer 1984, 54, 869-875. [CrossRef]

63. Deli, T.; Orosz, M.; Jakab, A. Hormone Replacement Therapy in Cancer Survivors-Review of the Literature. Pathol. Oncol. Res. 2020, 26, 63-78. [CrossRef] [PubMed]

64. Van Der Avoort, I.A.M.; Shirango, H.; Hoevenaars, B.M.; Grefte, J.M.M.; De Hullu, J.A.; De Wilde, P.C.M.; Bulten, J.; Melchers, W.J.G.; Massuger, L.F.A.G. Vulvar squamous cell carcinoma is a multifactorial disease following two separate and independent pathways. Int. J. Gynecol. Pathol. 2006, 25, 22-29. [CrossRef]

65. Post, M.D. Differentiated vulvar intraepithelial neoplasia contains Tp53 mutations and is genetically linked to vulvar squamous cell carcinoma. Yearb. Pathol. Lab. Med. 2011, 2011, 85-86. [CrossRef]

66. Mirghani, H.; Amen, F.; Tao, Y.; Deutsch, E.; Levy, A. Increased radiosensitivity of HPV-positive head and neck cancers: Molecular basis and therapeutic perspectives. Cancer Treat. Rev. 2015, 41, 844-852. [CrossRef]

67. Ciardiello, F.; Tortora, G. EGFR Antagonists in Cancer Treatment. N. Engl. J. Med. 2008, 358, 1160-1174. [CrossRef] [PubMed]

68. De Melo Maia, B.; Fontes, A.M.; Lavorato-Rocha, A.M.; Rodrigues, I.S.A.; De Brot, L.; Baiocchi, G.; Stiepcich, M.M.; Soares, F.A.; Rocha, R.M. EGFR expression in vulvar cancer: Clinical implications and tumor heterogeneity. Hum. Pathol. 2014, 45, 917-925. [CrossRef]

69. Woelber, L.; Hess, S.; Bohlken, H.; Tennstedt, P.; Eulenburg, C.; Simon, R.; Gieseking, F.; Jaenicke, F.; Mahner, S.; Choschzick, M. EGFR gene copy number increase in vulvar carcinomas is linked with poor clinical outcome. J. Clin. Pathol. 2012, 65, 133-139. [CrossRef]

70. Hicklin, D.J.; Ellis, L.M. Role of the vascular endothelial growth factor pathway in tumor growth and angiogenesis. J. Clin. Oncol. 2005, 23, 1011-1027. [CrossRef]

71. Dhakal, H.P.; Nesland, J.M.; Førsund, M.; Trope, C.G.; Holm, R. Primary Tumor Vascularity, HIF-1 $\alpha$ and VEGF expression in vulvar squamous cell carcinomas: Their relationships with clinicopathological characteristics and prognostic impact. BMC Cancer 2013, 13, 506. [CrossRef]

72. Obermair, A.; Kohlberger, P.; Bancher-Todesca, D.; Tempfer, C.; Sliutz, G.; Leodolter, S.; Reinthaller, A.; Kainz, C.; Breitenecker, G.; Gitsch, G. Influence of microvessel density and vascular permeability factor/vascular endothelial growth factor expression on prognosis in vulvar cancer. Gynecol. Oncol. 1996, 63, 204-209. [CrossRef]

73. Bancher-Todesca, D.; Obermair, A.; Bilgi, S.; Kohlberger, P.; Kainz, C.; Breitenecker, G.; Leodolter, S.; Gitsch, G. Angiogenesis in vulvar intraepithelial neoplasia. Gynecol. Oncol. 1997, 64, 496-500. [CrossRef]

74. Sherman, K.J.; Daling, J.R.; McKnight, B.; Chu, J. Hormonal factors in vulvar cancer: A case-control study. J. Reprod. Med. Obstet. Gynecol. 1994, 39, 857-861. [CrossRef]

75. Mirkin, S.; Pinkerton, J.V.; Kagan, R.; Thompson, J.R.; Pan, K.; Pickar, J.H.; Komm, B.S.; Archer, D.F. Gynecologic Safety of Conjugated Estrogens Plus Bazedoxifene: Pooled Analysis of Five Phase 3 Trials. J. Women's Health 2016, 25, 431-442. [CrossRef]

76. Sawaya, G.F.; Grady, D.; Kerlikowske, K.; La Valleur, J.; Barnabei, V.M.; Bass, K.; Snyder, T.E.; Pickar, J.H.; Agarwal, S.K.; Mandelblatt, J. The positive predictive value of cervical smears in previously screened postmenopausal women: The heart and estrogen/progestin replacement study (HERS). Ann. Intern. Med. 2000, 133, 942-950. [CrossRef]

77. Vargiu, V.; Amar, I.D.; Rosati, A.; Dinoi, G.; Turco, L.C.; Capozzi, V.A.; Scambia, G.; Villa, P. Hormone replacement therapy and cervical cancer: A systematic review of the literature. Climacteric 2021, 24, 120-127. [CrossRef] [PubMed]

78. Parazzini, F.; La Vecchia, C.; Negri, E.; Franceschi, S.; Moroni, S.; Chatenoud, L.; Bolis, G. Case-control study of oestrogen replacement therapy and risk of cervical cancer. Br. Med. J. 1997, 315, 85-88. [CrossRef] [PubMed]

79. Chung, S.H.; Lambert, P.F. Prevention and treatment of cervical cancer in mice using estrogen receptor antagonists. Proc. Natl. Acad. Sci. USA 2009, 106, 19467-19472. [CrossRef] [PubMed]

80. Ploch, E. Hormonal replacement therapy in patients after cervical cancer treatment. Gynecol. Oncol. 1987, 26, 169-177. [CrossRef]

81. Roura, E.; Travier, N.; Waterboer, T.; de Sanjosé, S.; Xavier Bosch, F.; Pawlita, M.; Pala, V.; Weiderpass, E.; Margall, N.; Dillner, J.; et al. The influence of hormonal factors on the risk of developing cervical cancer and pre-cancer: Results from the EPIC cohort. PLoS ONE 2016, 11, 0147029. [CrossRef]

82. Roig, L.M.V.; Lotfi, H.; Olcese, J.E.; Castro, G.L.; Ciocca, D.R. Effects of short-term tamoxifen administration in patients with invasive cervical carcinoma. Anticancer Res. 1993, 13, 2457-2463.

83. Bigler, L.R.; Thigpen, J.T.; Blessing, J.A.; Fiorica, J.; Monk, B.J. Evaluation of tamoxifen in persistent or recurrent nonsquamous cell carcinoma of the cervix: A Gynecologic Oncology Group study. Int. J. Gynecol. Cancer 2004, 14, 871-874. [CrossRef] [PubMed]

84. Cervical cancer and hormonal contraceptives: Collaborative reanalysis of individual data for 16573 women with cervical cancer and 35509 women without cervical cancer from 24 epidemiological studies. Lancet 2007, 370, 1609-1621. [CrossRef] 
85. Shields, T.S.; Falk, R.T.; Herrero, R.; Schiffman, M.; Weiss, N.S.; Bratti, C.; Rodriguez, A.C.; Sherman, M.E.; Burk, R.D.; Hildesheim, A. A case-control study of endogenous hormones and cervical cancer. Br. J. Cancer 2004, 90, 146-152. [CrossRef] [PubMed]

86. Rauh, L.A.; Pannone, A.F.; Cantrell, L.A. Hormone replacement therapy after treatment for cervical cancer: Are we adhering to standard of care? Gynecol. Oncol. 2017, 147, 597-600. [CrossRef] [PubMed]

87. Grenman, S.; Shapira, A.; Carey, T.E. In vitro response of cervical cancer cell lines CaSki, HeLa, and ME-180 to the antiestrogen tamoxifen. Gynecol. Oncol. 1988, 30, 228-238. [CrossRef]

88. Everhov, A.H.; Nyberg, T.; Bergmark, K.; Citarella, A.; Rådestad, A.F.; Hirschberg, A.L.; Smedby, K.E. Hormone therapy after uterine cervical cancer treatment: A Swedish population-based study. Menopause 2015, 22, 633-639. [CrossRef]

89. Iversen, L.; Fielding, S.; Lidegaard, Ø.; Hannaford, P.C. Contemporary hormonal contraception and cervical cancer in women of reproductive age. Int. J. Cancer 2021, 149, 769-777. [CrossRef]

90. Hridy, A.U.; Shabnaz, S.; Asaduzzaman, M.; Shahriar, M.; Bhuiyan, M.A.; Islam, M.S.; Hossen, S.M.M.; Emran, T.B. Genetic variations of RAD51 and XRCC2 genes increase the risk of colorectal cancer in Bangladeshi population. Asian Pac. J. Cancer Prev. 2020, 21, 1445-1451. [CrossRef]

91. Danforth, K.N.; Tworoger, S.S.; Hecht, J.L.; Rosner, B.A.; Colditz, G.A.; Hankinson, S.E. A prospective study of postmenopausal hormone use and ovarian cancer risk. Br. J. Cancer 2007, 96, 151-156. [CrossRef]

92. Puett, D.; Angelova, K.; da Costa, M.R.; Warrenfeltz, S.W.; Fanelli, F. The luteinizing hormone receptor: Insights into structurefunction relationships and hormone-receptor-mediated changes in gene expression in ovarian cancer cells. Mol. Cell. Endocrinol. 2010, 329, 47-55. [CrossRef]

93. Williams, C.; Simera, I. Tamoxifen for relapse of ovarian cancer. In Cochrane Database of Systematic Reviews; John Wiley \& Sons, Ltd.: Hoboken, NJ, USA, 2001. [CrossRef]

94. Langdon, S.P.; Herrington, C.S.; Hollis, R.L.; Gourley, C. Estrogen signaling and its potential as a target for therapy in ovarian cancer. Cancers 2020, 12, 1647. [CrossRef] [PubMed]

95. Symer, M.M.; Wong, N.Z.; Abelson, J.S.; Milsom, J.W.; Yeo, H.L. Hormone Replacement Therapy and Colorectal Cancer Incidence and Mortality in the Prostate, Lung, Colorectal, and Ovarian Cancer Screening Trial. Clin. Colorectal Cancer 2018, 17, e281-e288. [CrossRef] [PubMed]

96. Kavanagh, J.J.; Roberts, W.; Townsend, P.; Hewitt, S. Leuprolide acetate in the treatment of refractory or persistent epithelial ovarian cancer. J. Clin. Oncol. 1989, 7, 115-118. [CrossRef]

97. Bowman, A.; Gabra, H.; Langdon, S.P.; Lessells, A.; Stewart, M.; Young, A.; Smyth, J.F. CA125 Response Is Associated with Estrogen Receptor Expression in a Phase II Trial of Letrozole in Ovarian Cancer. Am. Assoc. Cancer Res. 2002, 6, $2233-2239$.

98. Papadimitriou, C.A.; Markaki, S.; Siapkaras, J.; Vlachos, G.; Efstathiou, E.; Grimani, I.; Hamilos, G.; Zorzou, M.; Dimopoulos, M.-A. Hormonal Therapy with Letrozole for Relapsed Epithelial Ovarian Cancer. Oncology 2004, 66, 112-117. [CrossRef] [PubMed]

99. Veenhof, C.H.N.; van der Burg, M.E.L.; Nooy, M.; Aalders, J.G.; Pecorelli, S.; Oliveira, C.F.; Rotmensz, N.; Vermorken, J.B. Phase II study of high-dose megestrol acetate in patients with advanced ovarian carcinoma. Eur. J. Cancer 1994, 30, 697-698. [CrossRef]

100. Post, M.D. Hormone-receptor expression and ovarian cancer survival: An Ovarian Tumor Tissue Analysis consortium study. Yearb. Pathol. Lab. Med. 2014, 2014, 113-115. [CrossRef]

101. Colon-Otero, G.; Weroha, S.J.; Foster, N.R.; Haluska, P.; Hou, X.; Wahner-Hendrickson, A.E.; Jatoi, A.; Block, M.S.; Dinh, T.A.; Robertson, M.W.; et al. Phase 2 trial of everolimus and letrozole in relapsed estrogen receptor-positive high-grade ovarian cancers. Gynecol. Oncol. 2017, 146, 64-68. [CrossRef]

102. Decruze, S.B.; Green, J.A. Hormone therapy in advanced and recurrent endometrial cancer: A systematic review. Int. J. Gynecol. Cancer 2007, 17, 964-978. [CrossRef]

103. Ghafarnegad, M.; Arjmand, N.; Khazaeipour, Z. Pregnancy rate of gonadotrophin therapy and laparoscopic ovarian electrocautery in polycystic ovary syndrome resistant to clomiphene citrate: A comparative study. Tehran Univ. Med. J. 2010, 67, 712-717.

104. Kirilovas, D.; Schedvins, K.; Naessén, T.; Von Schoultz, B.; Carlström, K. Conversion of circulating estrone sulfate to 17 $\beta$-estradiol by ovarian tumor tissue: A possible mechanism behind elevated circulating concentrations of $17 \beta$-estradiol in postmenopausal women with ovarian tumors. Gynecol. Endocrinol. 2007, 23, 25-28. [CrossRef]

105. Carter, J.; Pather, S. An overview of uterine cancer and its management. Expert Rev. Anticancer Ther. 2006, 6, 33-41. [CrossRef]

106. Seo, S.y.; Shin, J.Y.; Ji, Y. Il Metastatic uterine cancer looking as cervical fibroid in recurrent breast cancer woman: A case report. Obstet. Gynecol. Sci. 2017, 60, 481-484. [CrossRef]

107. Banno, K.; Kisu, I.; Yanokura, M.; Tsuji, K.; Masuda, K.; Ueki, A.; Kobayashi, Y.; Yamagami, W.; Nomura, H.; Susumu, N.; et al. Progestin therapy for endometrial cancer: The potential of fourth-generation progestin (Review). Int. J. Oncol. 2012, 40, 1755-1762. [CrossRef] [PubMed]

108. Ryu, H.; Choi, Y.S.; Song, I.C.; Yun, H.J.; Jo, D.Y.; Kim, S.; Lee, H.J. Long-term treatment of residual or recurrent low-grade endometrial stromal sarcoma with aromatase inhibitors: A report of two cases and a review of the literature. Oncol. Lett. 2015, 10, 3310-3314. [CrossRef] [PubMed]

109. Weiderpass, E.; Adami, H.O.; Baron, J.A.; Magnusson, C.; Bergström, R.; Lindgren, A.; Correia, N.; Persson, I. Risk of endometrial cancer following estrogen replacement with and without progestins. J. Natl. Cancer Inst. 1999, 91, 1131-1137. [CrossRef] [PubMed] 
110. Pike, M.C.; Peters, R.K.; Cozen, W.; Probst-Hensch, N.M.; Felix, J.C.; Wan, P.C.; Mack, T.M. Estrogen-Progestin Replacement Therapy and Endometrial Cancer. Obstet. Gynecol. Surv. 1998, 53, 285-287. [CrossRef]

111. Singh, S.S.; Belland, L. Contemporary management of uterine fibroids: Focus on emerging medical treatments. Curr. Med. Res. Opin. 2015, 31, 1-12. [CrossRef]

112. Reich, O.; Nogales, F.F.; Regauer, S. Gonadotropin-releasing hormone receptor expression in endometrial stromal sarcomas: An immunohistochemical study. Mod. Pathol. 2005, 18, 573-576. [CrossRef]

113. Zhang, Y.; Ding, J.X.; Tao, X.; Lu, Z.Y.; Wang, J.J.; Feng, W.W.; Hua, K.Q. Goserelin can inhibit ovarian cancer proliferation and simultaneously protect ovarian function from cisplatin: An in vitro and in vivo study. J. Chemother. 2013, 25, 96-103. [CrossRef]

114. Morgan, K.; Stewart, A.J.; Miller, N.; Mullen, P.; Muir, M.; Dodds, M.; Medda, F.; Harrison, D.; Langdon, S.; Millar, R.P. Gonadotropin-releasing hormone receptor levels and cell context affect tumor cell responses to agonist in vitro and in vivo. Cancer Res. 2008, 68, 6331-6340. [CrossRef]

115. Emons, G.; Gründker, C. The role of gonadotropin-releasing hormone (GnRH) in endometrial cancer. Cells 2021, 10, 292. [CrossRef]

116. Chlebowski, R.T.; Schottinger, J.E.; Shi, J.; Chung, J.; Haque, R. Aromatase inhibitors, tamoxifen, and endometrial cancer in breast cancer survivors. Cancer 2015, 121, 2147-2155. [CrossRef]

117. Altman, A.D.; Nelson, G.S.; Chu, P.; Nation, J.; Ghatage, P. Uterine sarcoma and aromatase inhibitors: Tom Baker cancer centre experience and review of the literature. Int. J. Gynecol. Cancer 2012, 22, 1006-1012. [CrossRef]

118. Thanopoulou, E.; Judson, I. Hormonal therapy in gynecological sarcomas. Expert Rev. Anticancer Ther. 2012, 12, 885-894. [CrossRef] [PubMed]

119. Bellone, S.; Shah, H.R.; McKenney, J.K.; Stone, P.J.B.; Santin, A.D. Recurrent endometrial carcinoma regression with the use of the aromatase inhibitor anastrozole. Am. J. Obstet. Gynecol. 2008, 199, e7-e10. [CrossRef] [PubMed]

120. Pink, D.; Lindner, T.; Mrozek, A.; Kretzschmar, A.; Thuss-Patience, P.C.; Dörken, B.; Reichardt, P. Harm or benefit of hormonal treatment in metastatic low-grade endometrial stromal sarcoma: Single center experience with 10 cases and review of the literature. Gynecol. Oncol. 2006, 101, 464-469. [CrossRef] [PubMed]

121. Spano, J.P.; Soria, J.C.; Kambouchner, M.; Piperno-Neuman, S.; Morin, F.; Morere, J.F.; Martin, A.; Breau, J.L. Long-term survival of patients given hormonal therapy for metastatic endometrial stromal sarcoma. Med. Oncol. 2003, 20, 87-93. [CrossRef] [PubMed]

122. Thigpen, J.T. The efficacy of hormonal treatment for residual or recurrent low-grade endometrial stromal sarcoma. A retrospective study. Yearb. Oncol. 2009, 2009, 57-58. [CrossRef]

123. Ramirez, P.T.; Frumovitz, M.; Bodurka, D.C.; Sun, C.C.; Levenback, C. Hormonal therapy for the management of grade 1 endometrial adenocarcinoma: A literature review. Gynecol. Oncol. 2004, 95, 133-138. [CrossRef]

124. Chu, M.C.; Mor, G.; Lim, C.; Zheng, W.; Parkash, V.; Schwartz, P.E. Low-grade endometrial stromal sarcoma: Hormonal aspects Gynecol. Oncol. 2003, 90, 170-176. [CrossRef]

125. Mizuno, M.; Yatabe, Y.; Nawa, A.; Nakanishi, T. Long-term medroxyprogesterone acetate therapy for low-grade endometrial stromal sarcoma. Int. J. Clin. Oncol. 2012, 17, 348-354. [CrossRef]

126. O'Cearbhaill, R.; Zhou, Q.; Iasonos, A.; Soslow, R.A.; Leitao, M.M.; Aghajanian, C.; Hensley, M.L. Treatment of advanced uterine leiomyosarcoma with aromatase inhibitors. Gynecol. Oncol. 2010, 116, 424-429. [CrossRef] [PubMed]

127. Leiser, A.L.; Hamid, A.M.; Blanchard, R. Recurrence of prolactin-producing endometrial stromal sarcoma with sex-cord stromal component treated with progestin and aromatase inhibitor. Gynecol. Oncol. 2004, 94, 567-571. [CrossRef]

128. Murphy, N.J.; Wallace, D.L. Gonadotropin releasing hormone (GnRH) agonist therapy for reduction of leiomyoma volume Gynecol. Oncol. 1993, 49, 266-267. [CrossRef]

129. Wang, C.B.; Wang, C.J.; Huang, H.J.; Hsueh, S.; Chou, H.H.; Soong, Y.K.; Lai, C.H. Fertility-preserving treatment in young patients with endometrial adenocarcinoma. Cancer 2002, 94, 2192-2198. [CrossRef]

130. Kung, F.T.; Chen, W.J.; Chou, H.H.; Ko, S.F.; Chang, S.Y. Conservative management of early endometrial adenocarcinoma with repeat curettage and hormone therapy under assistance of hysteroscopy and laparoscopy. Hum. Reprod. 1997, 12, 1649-1653. [CrossRef]

131. Huang, S.Y.; Jung, S.M.; Ng, K.K.; Chang, Y.C.; Lai, C.H. Ovarian metastasis in a nulliparous woman with endometrial adenocarcinoma failing conservative hormonal treatment. Gynecol. Oncol. 2005, 97, 652-655. [CrossRef] [PubMed]

132. Chang, W.H.; Chen, C.H.; Yu, M.H. Conservative therapy of stage I endometrial adenocarcinoma and atypical endometrial hyperplasia for the preservation of fertility. Int. J. Gynecol. Obstet. 2006, 92, 137-138. [CrossRef] [PubMed]

133. Ahmed, S.; Rakib, A.; Islam, M.A.; Khanam, B.H.; Faiz, F.B.; Paul, A.; Chy, M.N.U.; Bhuiya, N.M.M.A.; Uddin, M.M.N.; Ullah, S.M.A.; et al. In vivo and in vitro pharmacological activities of Tacca integrifolia rhizome and investigation of possible lead compounds against breast cancer through in silico approaches. Clin. Phytoscience 2019, 5, 36. [CrossRef]

134. Milewich, L.; Porter, J.C. In situ steroid sulfatase activity in human epithelial carcinoma cells of vaginal, ovarian, and endometrial origin. J. Clin. Endocrinol. Metab. 1987, 65, 164-169. [CrossRef] [PubMed]

135. Simon, J.; Nachtigall, L.; Ulrich, L.G.; Eugster-Hausmann, M.; Gut, R. Endometrial safety of ultra-low-dose estradiol vaginal tablets. Obstet. Gynecol. 2010, 116, 876-883. [CrossRef]

136. Minkin, M.J.; Maamari, R.; Reiter, S. Improved compliance and patient satisfaction with estradiol vaginal tablets in postmenopausal women previously treated with another local estrogen therapy. Int. J. Womens. Health 2013, 5, 133-139. [CrossRef] 
137. Alvisi, S.; Baldassarre, M.; Martelli, V.; Gava, G.; Seracchioli, R.; Meriggiola, M.C. Effects of ospemifene on vaginal epithelium of post-menopausal women. Gynecol. Endocrinol. 2017, 33, 946-950. [CrossRef]

138. Bachmann, G.A.; Komi, J.O. Ospemifene effectively treats vulvovaginal atrophy in postmenopausal women: Results from a pivotal phase 3 study. Menopause 2010, 17, 480-486. [CrossRef] [PubMed]

139. Jacob, L.; Kostev, K.; Kalder, M. Prescription of hormone replacement therapy prior to and after the diagnosis of gynecological cancers in German patients. J. Cancer Res. Clin. Oncol. 2020, 146, 1567-1573. [CrossRef] [PubMed]

140. Portman, D.J.; Bachmann, G.A.; Simon, J.A. Ospemifene, a novel selective estrogen receptor modulator for treating dyspareunia associated with postmenopausal vulvar and vaginal atrophy. Menopause 2013, 20, 623-630. [CrossRef]

141. Kagan, R.; Williams, R.S.; Pan, K.; Mirkin, S.; Pickar, J.H. A randomized, placebo-and active-controlled trial of bazedoxifene/ conjugated estrogens for treatment of moderate to severe vulvar/vaginal atrophy in postmenopausal women. Menopause 2010, 17, 281-289. [CrossRef]

142. Bachmann, G.; Bobula, J.; Mirkin, S. Effects of bazedoxifene/conjugated estrogens on quality of life in postmenopausal women with symptoms of vulvar/vaginal atrophy. Climacteric 2010, 13, 132-140. [CrossRef]

143. Mirkin, S.; Simon, J.A.; Liu, J.H.; Archer, D.F.; Castro, P.D.; Graham, S.; Bernick, B.; Komm, B. Evaluation of endometrial progesterone receptor expression after 12 weeks of exposure to a low-dose vaginal estradiol insert. Menopause 2021, 28, 998-1003. [CrossRef]

144. Capriglione, S.; Plotti, F.; Montera, R.; Luvero, D.; Lopez, S.; Scaletta, G.; Aloisi, A.; Serra, G.B.; Angioli, R. Role of paroxetine in the management of hot flashes in gynecological cancer survivors: Results of the first randomized single-center controlled trial. Gynecol. Oncol. 2016, 143, 584-588. [CrossRef]

145. Santen, R.J. Menopausal hormone therapy and breast cancer. J. Steroid Biochem. Mol. Biol. 2014, 142, 52-61. [CrossRef] [PubMed]

146. Lower, E.E.; Blau, R.; Gazder, P.; Stahl, D.L. The effect of estrogen usage on the subsequent hormone receptor status of primary breast cancer. Breast Cancer Res. Treat. 1999, 58, 205-210. [CrossRef]

147. Legha, S.S.; Davis, H.L.; Muggia, F.M. Hormonal therapy of breast cancer: New approaches and concepts. Ann. Intern. Med. 1978, 88, 69-77. [CrossRef] [PubMed]

148. Rugo, H.S.; Vidula, N.; Ma, C. Improving Response to Hormone Therapy in Breast Cancer: New Targets, New Therapeutic Options. Am. Soc. Clin. Oncol. Educ. B. 2016, 36, e40-e54. [CrossRef] [PubMed]

149. Schenck-Gustafsson, K.; Brincat, M.; Erel, C.T.; Gambacciani, M.; Lambrinoudaki, I.; Moen, M.H.; Tremollieres, F.; Rozenberg, S.V.S.; Rees, M. EMAS position statement: Managing the menopause in the context of coronary heart disease. Maturitas 2011, 68, 94-97. [CrossRef]

150. Lakoski, S.G.; Herrington, D.M. Effects of hormone therapy on C-reactive protein and IL-6 in postmenopausal women: A review article. Climacteric 2005, 8, 317-326. [CrossRef]

151. Rauf, A.; Abu-Izneid, T.; Khalil, A.A.; Imran, M.; Shah, Z.A.; Emran, T.B.; Mitra, S.; Khan, Z.; Alhumaydhi, F.A.; Aljohani, A.S.; et al. Berberine as a potential anticancer agent: A comprehensive review. Molecules 2021, 26, 7368. [CrossRef]

152. Reeves, G.K.; Beral, V.; Green, J.; Gathani, T.; Bull, D. Hormonal therapy for menopause and breast-cancer risk by histological type: A cohort study and meta-analysis. Lancet Oncol. 2006, 7, 910-918. [CrossRef]

153. Ye, F.; Wen, J.; Yang, A.; Wang, Y.; Li, N.; Yu, P.; Wei, W.; Tang, J. The Influence of Hormone Therapy on secondary diabetes mellitus in Breast Cancer: A Meta-analysis. Clin. Breast Cancer 2021, 22, e48-e58. [CrossRef]

154. Heit, J.A.; Silverstein, M.D.; Mohr, D.N.; Petterson, T.M.; O’Fallon, W.M.; Melton, L.J. Risk factors for deep vein thrombosis and pulmonary embolism: A population-based case-control study. Arch. Intern. Med. 2002, 160, 809-815. [CrossRef] [PubMed]

155. Carugno, J. Clinical management of vaginal bleeding in postmenopausal women. Climacteric 2020, 23, 343-349. [CrossRef] [PubMed]

156. Beral, V.; Reeves, G.; Bull, D.; Green, J. Breast cancer risk in relation to the interval between menopause and starting hormone therapy. J. Natl. Cancer Inst. 2011, 103, 296-305. [CrossRef] [PubMed] 